\title{
Türkiye'de Merkezi Yönetimin Sosyal Medya Kullanımı: Bakanlıkların Twitter Hesapları Üzerine Bir Analiz
}

\author{
The Social Media Usage of Central Government in Turkey: An Analysis on the Twitter Accounts of \\ Ministries
}

\section{Volkan GöÇOĞLU}

Dr. Öğr. Üyesi, Afyon Kocatepe Üniversitesi,

Dinar Uygulamalı Bilimler Yüksekokulu,

volkangocoglu@gmail.com

https://orcid.org/0000-0002-7036-2416
Makale Başvuru Tarihi: 02.08.2019

Makale Kabul Tarihi: 24.09.2019

Makale Türü: Araştırma Makalesi

\section{ÖZET}

Anahtar

Kelimeler:

Merkezi Yönetim,

Bakanlıklar,

Sosyal Medya,

Twitter,

Keywords:

Centralized

Adminstration,

Ministries,

Social Media,

Twitter,
Internet kullanımının dünya genelinde yaygınlaşması ile birlikte internet tabanlı uygulama ve yazılımları da gelişmiş ve çeşitlenmiştir. Bu gelişme neticesinde internet tek taraflı bilgi paylaşım ağ olmaktan öteye giderek insanların ve kurumların bilgiyi birbirleriyle etkileşimde bulunarak paylaştığı bir platform haline gelmiştir. Sosyal medya bu durumun bir yansıması olarak ortaya çıkmıştır. Sosyal medya kullanımı özellikle 2000 'li yılların başından bu yana önemli ölçüde yaygınlaşmıştır. Son yıllarda devlet kurumları da sosyal medyayı aktif kullanır hale gelmiştir. Bu çalışma, Türkiye'deki bakanlıkların sosyal medya kullanımlarını önde gelen bir sosyal medya platformu olan Twitter üzerinden analiz etmektedir. Çalışmada, bakanlıkların 2019 yllında paylaştıkları toplam 8883 adet tweet incelenerek, kurumların bu tweetleri hangi amaçlarla paylaşıldığı belirlenmeye çalışılmıştır. 


\section{GIRISS}

Gelişen bilgi teknolojileri, yaygınlaşan internet kullanımı ile birlikte insanların ve kurumların bilgiye daha kolay ulaşmasını sağlayacak oluşumları beraberinde getirmiştir. Söz konusu oluşumlar öncelikle bilgiyi insanlara tek taraflı sunan kişisel ve kurumsal internet siteleri, bloglar, online ansiklopediler olarak hayata geçmiştir. Sonraki dönemlerde ise bilgi alışverişini tek taraflı olmaktan çift taraflı olmaya eviren sanal oluşumlar ortaya çıkmıştır. İnteraktif blog siteleri, açık kaynaklı ansiklopediler, katılımlı paylaşım portalları (torrentler) ve nihayet sosyal medya platformları internetin vazgeçilmezleri arasına girmiştir. O'Reilly (2007), bilgi alışverişindeki "tek taraflıdan çift taraflı akışa geçme" sürecini iki ayrı dönem olarak ele almıştır. Ona göre internetin Britannica Online, mp3.com, Ofoto gibi siteler aracılığıyla kullanıcılara tek taraflı bilgi sunduğu dönem Web 1.0 dönemidir. Sosyal medyanın ortaya çıkması, internet sitelerinin ve programlarının hem kullanıcıya bilgi verme hem de kullanıcıdan bilgi alma gibi çift fonksiyon kazandığı, Wikipedia, Napster, Youtube, Facebook, Twitter gibi interaktif ve katılımcı platformların yaygın olarak kullanılmaya başladığı dönem ise Web 2.0 dönemidir. Bilginin paylaşım yönünün değişimini yansıtan bu iki dönem aynı zamanda söz konusu platformların kullanım amaçlarının değişimini de beraberinde getirmiştir. Web 2.0'ın en önde gelen platformlarından olan sosyal medya, kamu kurumlarınca da hem vatandaşa bilgi vermek hem de vatandaştan dönüt almak için kullanılır olmuştur. Hem merkezi yönetime bağlı kurum ve kuruluşlar hem de belediyeler kendilerine Facebook, Twitter, Youtube gibi önde gelen çeşitli sosyal medya platformlarında resmi kullanıcı hesapları açmaya ve sosyal medyayı bu amaçla aktif şekilde kullanmaya başlamışlardır.

Modern demokrasilerde ve yönetimlerde politikacıların üretecekleri politikalara doğrudan etkide bulunan veya bulunması gereken unsurlar vatandaşlar ve kamuoyudur. Sosyal medya kullanımının yaygınlaşması, politikacılar ile vatandaşlar arasındaki etkileşimi hızlandırmıştır. $\mathrm{Bu}$ sayede, vatandaşların üretilen kamu politikalarına karşı tepkilerini ilgili mercilere ulaşmasını kolaylaştırmıştır. Aynı şekilde politikacıların yaptıkları uygulamalardan dolayı bu platformlardan halka hesap vermesi de kolaylaşmışıtır (Çildan vd., 2012:3). Sosyal medya ile birlikte vatandaşlar, kurumların ilgili birimlerine telefon, dilekçe ya da mektup yerine, yorum, tweet, whatsapp mesaj1 vb. sosyal medya iletileriyle ulaşabilir hale gelmişlerdir (McNutt, 2012:13; Göçoğlu, 2014:70). Bu gelişmeler, kamu kurumlarının sosyal medya kullanımını gün geçtikçe bir gereklilik ve bunun ötesinde bir kamu hizmeti haline gelmesini sağlamıştır. Bu çalışma, ele alınan bu hususlar doğrultusunda, sosyal medya ve kullanımının iyiden iyiye olgunlaştı̆̆ı bu dönemde, "Türkiye'deki bakanlıklar sosyal medyayı hangi fonksiyonlarda kullanmaktadır?" araştırma sorusuna cevap olarak, Türkiye'deki bakanlıkların sosyal medya kullanım eğilimlerini analiz etmeyi amaçlamaktadır. Çalışmanın ilk bölümünde kamu kurum ve kuruluşlarının sosyal medya kullanımları ilgili literatür temelinde ele alınmıştır. Çalışmanın ikinci bölümünde ise bakanlıkların sosyal medya hesapları üzerinde gerçekleştirilen bir içerik analizine yer verilmiştir. Bakanlıkların hangi sosyal medya platformlarını öncelikli olarak kullandıkları, hangi sosyal medya platformlarını ne amaçlarla kullandıkları (kurumsal bilgilendirme, kamu spotu, politika sunumu, bayram/özel gün kutlama, vatandaştan fikir alma/anket) gibi kriterler bu analiz kapsamında sorgulanmıştır. Araştırmanın sonuç kısmında ise analizden elde edilen bulgular doğrultusunda tanımlayıcı sonuçlar ortaya konmuştur.

\section{LITERATÜR TARAMASI}

Kamu kurum ve kuruluşlarında sosyal medya kullanımının son yıllarda bilgi iletişim teknolojilerinde yaşanan gelişmeler ile internet kullanımının yaygınlaşmasına bağlı olarak geliştiğini iddia etmek yanlış bir savunu olmayacaktır. Bu sebep-sonuç ilişkisinde, çevrenin geldiği nokta ve buna bağlı olarak ortaya çıkan itici gücün yanında, temelde birtakım devlet ve yönetim teorilerinin de etkisinin olduğunu atlamamak gerekmektedir. Hiç kuşkusuz Yeni Kamu İşletmeciliği (YKİ) (Osborne ve Gaebler, 1992) anlayışının getirdiği devlette verimlilik, etkinlik, etkililik, şeffaflık ve hesap verebilirlik ilkelerinin benimsenme ve uygulanma çabası dolaylı olarak kamu kurumlarında sosyal medya kullanımını desteklemiştir. Buna genel ve somut bir örnek verilecek olursa Amerika Birleşik Devletlerinde (ABD), Barack Obama döneminde Beyaz Saray tarafından yayınlanan memorandumda "Şeffaf Hükümet Direktifi" (Open Government Directive) yer almış ve yönetimde şeffaflık, vatandaş katılımı ve işbirliği ilkeleri vurgulanmıştır (White House, 2009). Söz konusu direktifte ayrıca her bir kamu kurumunun kendi resmi internet sitesinde faaliyetleri, bilgi edinme hakk1, organizasyon şeması, analiz ve koordinasyon kapasitesi gibi verilerinin vatandaşlara sunulması şar koşulmuştur (McDermott, 2010:412). Diğer yandan devlet kurumlarında sosyal medya kullanımını, Denhardt'ların 2000'li yılların hemen başında, YKİ anlayışına eleştiri olarak ortaya koydukları Yeni Kamu Hizmetinin (YKH) "Hizmet" fonksiyonunun çağı yakalamış bir uzantısı olarak gören araştırmacılar da vardır (Brainard ve McNutt, 2010:839). 
Rooksby ve Sommerville'nin (2012:399) altını çizdiği üzere, dönemin ABD Başkanı Obama, söylemlerinde direkt olarak söz etmese de Web 2.0 ve getirilerinin kamu kurum ve kuruluşlarının kendi aralarında, özel sektör şirketleriyle ve vatandaşlarla iletişim ve etkileşimi artırmak üzere kullanılmasına vurgu yapmıştır. Diğer yandan İngiltere İç işleri Bakanlığının sosyal medya kullanımı da çalışmada derinlemesine incelenmiştir. Sosyal medyayı vatandaş ve diğer organizasyonlarla iletişimde aktif bir şekilde kullanan bakanlığın, hitap ettiği sosyal medya kullanıcısı kitlesinin büyümesi ve taleplerinin artmasıyla karşı karşıya kaldığı sosyal medya yönetim sorununun altını çizmişlerdir. Yazarlar (Rooksby ve Sommerville, 2012:408-411), bakanlıktan örnekle kamu kurum ve kuruluşlarında sosyal medya yönetiminde ortaya çıkabilecek muhtemel sorunları elle almışlardır. Kurumda "sosyal medya yönetiminin sınırları" ilk sorun olarak belirtilmiştir. Burada iç yönetim ve dış yönetim olarak iki fonksiyondan bahsedilmektedir. İç yönetim, daha çok bakanlık personelinin ve bakanlıkla bağlı olarak dış bir firmada ya da organizasyonda çalışan personelin kurum içi ve kendi sosyal yaşantısı için sosyal medya kullanımının yönetilmesidir. Dış yönetim ise kurumun sosyal medya hesaplarının kurumun vatandaş ya da diğer organizasyonlarla iletişimi için kullanılmasıdır. Bu iki yönetimde de belirli prosedür ve normların belirlenmesi ve uygulanması gerekmektedir. Diğer bir sorun ise "sınırlı kontrol" sorunudur. Bakanlıkların internette yer edinmiş tüm sosyal medya platformlarını aktif olarak kullanması ve bunları yönetmesi oldukça zordur. Bu yüzden bakanlıklar bunlar arasından belirli platformları seçmelidirler. Seçilen platformlarda da kontrolün sınırı ise insan kaynağına ve bu kaynağın yeteneklerine bağlıdır. Gözlemleme sorunları da bakanlıkların sosyal medya kullanımlarında göze çarpmaktadır. Zira sosyal medya platformlarında vatandaşlar yalnızca bakanlık tarafindan paylaşılan gönderileri görebilmektedir. Bunların daha gelişmiş sistemleri olarak, bakanlıkların kendi internet sitelerinde faaliyetlerin sunulması, birimlerin kamera ile gözlemlenebilmesi gibi imkânlar olsa da, kurumlar bu gibi uygulamaları, siber güvenlik kaygılarıyla bu platformlara yansıtmamayı tercih edebileceklerdir. Diğer yandan sosyal medya sitelerinin birbirleri ile bağlantılı olması (birbirleri arasında paylaşım yapılabilmesi, ortak kullanıcı verileri kullanması) durumu, kurumun sosyal medya yöneticileri iyi yönetilmelidir. Son olarak sosyal medya platformları sürekli güncellenen ve yeni uygulamalar geliştirerek edinen platformlardır. Yöneticiler bu değişimlere de ayak uydurmalılardır.

Sosyal medyanın doğasında iş birliği ve katılımcılık vardır. Devlet kurumlarının sosyal medyayı kullanma amaçları da öncelikle bilgi verme amaçlı olmanın yanında, etkileşimi ve sosyal medyanın doğasında olduğu üzere işbirliği ve katılımı desteklemektir (Khan vd., 2014a:62). Bu yönüyle sosyal medya ülkelerin devlet kurumlarınca vatandaşlarla etkileşim kurmak üzere kullanılmakta ve bu kullanım gün geçtikçe gelişmektedir. $\mathrm{Bu}$ duruma örnek olarak Khan ve arkadaşlarının (2014b) Güney Kore üzerinde yaptıkları çalışma gösterilebilecektir. Çalışmanın sonuçlarına göre ülkedeki kamu kurumlarının kurumlar arası etkileşimde kullanımı oldukça yaygındır ancak kurumların direkt olarak vatandaşları hedef alan ve onları sosyal medya aktivitelerine katılıma teşvik etmek üzere kullanımı zayıf kalmaktadır. Çalışmada ortaya konulan ana öneri ise kurumların, sosyal medya üzerinden işbirliği ve katılım ile vatandaşların ihtiyaçlarını karşılayabilecek seviyeye gelmesidir. Yine Güney Kore'nin Gıda, Tarım ve Orman Bakanlığının Twitter kullanımı üzerine yapılan başka bir çalışmada (Cho ve Park, 2012), bakanlığın bu sosyal medya platformunu yoğun olarak kullandığ belirlenirken, diğer çalışmadan ayrı olarak, bu kullanımın sadece kurumdan vatandaşlara ve vatandaşlardan kuruma yönlü bir iletişimi sağlamadığını ortaya çıkarmıştır. Çalışmada yapılan ağ analizinde, vatandaşların, kurum sosyal medya hesapları üzerinden belirli politika ve konulara karşı kuruma karşı da işbirliklerinde bulunmak üzere iletişime geçtiklerinin altı çizilmiştir. Bergquist ve arkadaşları (2017) ise devlet kurumlarının sosyal medyada vatandaşlarla etkileşimde olmasının, bu platformda kurumlar tarafindan tanıtılan ve hakkında bilgi verilen politikaların kamuoyu nezdinde meşruiyet kazanmasına olumlu etki ettiğini vurgulamaktadırlar.

Chun ve arkadaşları (2010:5), daha önce bahsi geçen ve sosyal medyanın da bir çıktısı olduğu Web 2.0'1, kamu yönetimi ile birlikte ele almış ve sosyal medyayı vatandaşlarla etkileşim için kullanan kamu yönetimini Devlet 2.0 olarak nitelendirmiştir. Onlara göre Devlet 2.0, vatandaşlar, devlet ve veri arasında bağlantı sağlayan bir olgudur. Devlet 2.0'dan önceki yapı ise Geleneksel Dijital Devlet (GDD) olarak isimlendirilmiştir. GDD bilgi sağlayıcı iken Devlet 2.0 bilginin kaynağı, GDD servis sağlayıcı iken Devlet 2.0 servis talebi alan, GDD politikayı dayatan iken Devlet 2.0 politikayı münazara eden ve yönetişimi sağlayan yapı olarak betimlenmiştir. Bertot ve arkadaşları (2012) ise sosyal medyanın devlet kurumları tarafından yoğun olarak kullanılmaya başlanması ile birlikte yapılan ve yapılacak hukuki düzenlemelerin öneminin arttığının altını çizmişlerdir. Yazarlara göre mahremiyet, güvenlik, bilgi yönetimi, ulaşılabilirlik, sosyal içerme ve yönetişim gibi konular, kurumların sosyal medya kullanımında belirli hukuki düzenlemelerle ele alınmalı ve geliştirilmelidir.

Türkiye'de de kamu kurumlarının sosyal medyaya verdiği önem gelinen dönemde bir hayli artmıştır. Bu durum bakanlıkların stratejik planlarında siber güvenliğe dolaylı ya da direkt olarak yer vermelerinden kolayca anlaşılabilmektedir. Gülaslan'ın (2018) çalışmasında yer verdiği üzere, Gençlik ve Spor Bakanlığının 20182022 stratejik planında "stratejik yönetim anlayışı ile etkin ve verimli hizmet sunabilmek amactyla kurumsal 
kapasitenin gelişimini sürdürmek ve çalışanların kurumsal bağlılığını güçlendirmek" stratejik amacını gerçekleştirmek üzere, "web siteleri, sosyal medya platformları, mobil teknolojiler kullanılarak hedef kitleye en etkili yoldan ulaşmak ve alınan geri dönüşler sonucunda hizmet kalitesini artırmak" stratejisi buna somut bir örnek olarak verilebilecektir. Diğer yandan çalışmada (o dönemdeki isimleriyle) Gümrük ve Ticaret Bakanlığ 1 , Orman ve Su İşleri Bakanlığı, Sağlık Bakanlığı, Ulaştırma Denizcilik ve Haberleşme Bakanlığı, Avrupa Birliği Bakanlığı ve Gıda ve Tarım ve Hayvancılık Bakanlığının dönem strateji belgelerinde sosyal medyanın da yer aldığının altı çizilmektedir. Bu kapsamda, Türkiye'de bakanlıkların önemli bir sosyal medya platformu olan Twitter kullanımları, bir sonraki bölümde derinlemesine analiz edilecektir.

\section{ARAȘTIRMANIN YÖNTEMI}

$\mathrm{Bu}$ araştırmada Türkiye'deki bakanlıkların sosyal medya kullanımları, bu platformların kurumlar tarafından kullanım amaç ve fonksiyonları temelinde incelenmektedir. Araştırmada öncelikli olarak, bakanlıkların sosyal medya platformlarını hangi fonksiyonlarla kullandıklarını analiz etmek için 16 bakanlığın resmi Twitter hesapları yüzeysel olarak incelenmiştir. Yapılan inceleme sonucunda bakanlıkların Twitter'daki tweetlerinin genel olarak şu altı fonksiyonda kullanıldığı belirlenmiştir:

Bakanın kendi Twitter hesabından paylaştığı tweetleri retweet yapma

- Bakanlık tarafindan kamuoyuna kurumsal bilgilendirme

Kamu spotu yayınlama

* Bayram, özel gün kutlama/başsağlığı, anma

* Diğer kurumlarla etkileşim/diğer kurumlardan ya da devlet adamlarından retweet yapma

Yukarıda sıralanan genel fonksiyonlar bağlamında, analiz için 6 adet kod üretilmiş ve bu kodlar temelinde bakanlıkların resmi Twitter hesapları üzerinde tweet metni ve içeriğinin incelenerek araştırmacı tarafından yorumlanmak suretiyle ilgili kodlara yerleştirildiği bir içerik analizi (Taşvanc1l ve Aslan, 2001) gerçekleştirilmiştir. Kullanılacak kodlar, Bakandan Retweet, Kurumsal Bilgilendirme/Politika Bildirimi, Kamu Spotu, Bayram/Özel Gün Kutlama/Anma/Başsağlığı, Diğer Kurumlarla Etkileşim ve Vatandaştan Fikir Alma/Anket olarak belirlenmiştir. Belirlenen "Vatandaştan Fikir Alma/Anket" kodu, tweetlerin genel fonksiyonlarını belirlemek için yapılan yüzeysel incelemede öne çıkan bir kod değildir. Araştırmacı bu kodu özellikle bakanlıkların Twitter kullanımlarının sivil katılım, vatandaştan belirli politikalar için fikir alma boyutuna da odaklanabilmek için eklenmiştir. Bunun ötesinde Twitter'ın hâlihazırda bu iş için anket uygulamasının bulunması da bu seçime önemli etkide bulunmuştur. Örneklem olarak, çıkarımların daha güncel olması ve araştırmanın kapsam olarak daha makul bir veri setinde değerlendirilebilmesi bakımından, bakanlıkların 2019 yılında attıkları tweetler belirlenmiş ve her bir bakanlığın 2019 yılı Temmuz ayına kadar (Temmuz ayı dâhil olmak üzere) attıkları toplam 8883 adet tweet içerik analizine tabi tutulmuştur. Dolayısıyla bulgulardan yapılacak olan çıkarsamalar, bakanlıkların 2019 yılı Twitter kullanımlarına ait olacaktır. Bakanlıkların bünyesinde bulunan müdürlüklerin attıkları tweetler de kurum tweetleri olarak ele alınmıştır ancak bakanlıkların taşra örgütleri, bağlı, ilgili, ilişkili kuruluşları ile bünyelerinde oluşturdukları kampanya, platform vb. organizasyonların paylaştıkları tweetler bu kapsamda ele alınmamıştır. Bunlardan yapılan retweetler, "Diğer kurumlarla etkileşim" kodu kapsamında değerlendirilmiştir. Araştırmacı tarafından okunan tweetler, yine araştırmacı tarafından yorumlanarak, belirlenen kodlardan birine dâhil edilmiştir. Tweetlerin kodlar çerçevesinde daha pratik bir şekilde gruplandırılabilmesi, bulguların sayısallaştırılabilmesi ve görselleştirilebilmesi için IBM SPSS Statistics 22 veri analizi programından faydalanılmıştır. 


\section{BULGULAR}

Araştırmanın ilk bulguları, bakanlıkların resmi Twitter hesaplarının genel durumlarına ilişkindir. Bu doğrultuda, bakanlıkların resmi Twitter hesaplarındaki takipçi sayıları, takip ettikleri hesap sayısı, resmi hesap tarafindan paylaşılan toplam tweet sayıları ve kurumların bu araştırmada incelenen, 2019 yılında Temmuz ayına kadar paylaştıkları tweet sayıları aşağıdaki tabloda sunulmaktadır.

Tablo 1. Bakanlıkların Resmi Twitter Hesapları ve Genel Bilgiler ${ }^{1}$

\begin{tabular}{|c|c|c|c|c|}
\hline Bakanlık Adı & Takipçi & Takip Edilen & Toplam Tweet & İncelenen Tweet \\
\hline T. C. Sağlık Bakanlığı & $473,1 \mathrm{~B}$ & 15 & $15,3 \mathrm{~B}$ & 815 \\
\hline T. C. İçişleri Bakanlığ1 & $669 \mathrm{~B}$ & 10 & 2,632 & 516 \\
\hline T. C. Dışişleri Bakanlığ1 & $1,3 \mathrm{Mn}$ & 261 & $13,9 \mathrm{~B}$ & 823 \\
\hline T. C. Gençlik ve Spor Bakanlığ 1 & $257,7 \mathrm{~B}$ & 18 & $14,4 \mathrm{~B}$ & 443 \\
\hline T. C. Ulaştırma ve Altyapı Bakanlığı & $139,1 \mathrm{~B}$ & 50 & $11,4 \mathrm{~B}$ & 811 \\
\hline T. C. Milli Eğitim Bakanlığı & $501 \mathrm{~B}$ & 21 & 3,890 & 453 \\
\hline T. C. Milli Savunma Bakanlığ 1 & $383,2 \mathrm{~B}$ & 2 & 2710 & 793 \\
\hline T. C. Ticaret Bakanlığ1 & $39,2 \mathrm{~B}$ & 86 & 1631 & 276 \\
\hline T. C. Hazine ve Maliye Bakanlığ 1 & $159,8 \mathrm{~B}$ & 18 & 871 & 82 \\
\hline T. C. Enerji ve Tabii Kaynaklar Bakanlığı & $85,1 \mathrm{~B}$ & 26 & 714 & 213 \\
\hline T. C. Adalet Bakanlığ1 & $355,9 \mathrm{~B}$ & 29 & 1336 & 194 \\
\hline T. C. Tarım ve Orman Bakanlığı & $107,5 \mathrm{~B}$ & 38 & 3363 & 838 \\
\hline T. C. Sanayi ve Teknoloji Bakanlığı & $142,8 \mathrm{~B}$ & 149 & 9644 & 567 \\
\hline T. C. Aile, Çalışma ve Sosyal Hizmetler Bakanlığı & $275,4 \mathrm{~B}$ & 342 & $12 \mathrm{~B}$ & 797 \\
\hline T. C. Kültür ve Turizm Bakanlığ 1 & $117,4 \mathrm{~B}$ & 47 & $11,8 \mathrm{~B}$ & 670 \\
\hline T. C. Çevre ve Şehircilik Bakanlığ 1 & $119,3 \mathrm{~B}$ & 67 & 3794 & 592 \\
\hline TOPLAM İNCELENEN TWEET & & & & 8883 \\
\hline
\end{tabular}

Kaynak: Yazar tarafindan hazırlanmıştır.

Bakanlıkların resmi Twitter hesaplarının genel durumlarına bakıldığında, en çok dikkat çeken nokta, Dışişleri Bakanlığının takipçi sayısının diğer bakanlıklardan açık ara önde olduğudur. $\mathrm{Bu}$, sosyal medya kullanıcı vatandaşların, ülke politikalarından en çok dış politikaya önem verdiğini göstermektedir. Bunun yanında, Dışişleri bakanlığının resmi hesabından paylaşmış olduğu tweet sayısı da bir hayli fazladır. Twitter hesabının bakanlık tarafından aktif olarak kullanılıyor olmasının, kurumun Twitter'da takipçi sayısının fazla olmasına olumlu etki ettiği düşünülmektedir. Takipçi sayısı en az olan bakanlık, Ticaret Bakanlığı olarak belirlenmiştir. Resmi Twitter hesabında en fazla tweet paylaşan bakanlık, Sağlık Bakanlığıdır. En fazla Twitter hesabı takip eden bakanlık ise Aile, Çalışma ve Sosyal Hizmetler Bakanlığıdır.

Araştırmanın bakanlıklar üzerindeki spesifik bulguları ise bakanlıkların Twitter hesaplarında 2019 yılında (Temmuz ayı sonuna kadar) paylaştıkları tweetlerin belirlenen kodlar bağlamında içerik analizine tabi tutulması neticesinde ortaya çıkmıştır. Bu doğrultuda aşağıda, bakanlıkların Twitter hesaplarında paylaştıkları tweetler ve

1 Tablodaki veriler, 2019 y1lı, Temmuz ayına aittir. 
bunların kodlar arasındaki dağılımı tablolar çerçevesinde sayısal ve pasta dilimi grafikler desteğiyle görsel olarak sunulacaktır.

Tablo 2. Sağlık Bakanlığının Tweetlerinin Kodlar Arası Dağılımı

\begin{tabular}{|c|c|c|}
\hline Kodlar & Tweet Sayısı & Oran (\%) \\
\hline Bakandan Retweet & 380 & 46,6 \\
\hline Kurumsal Bilgilendirme/Politika Bildirimi & 141 & 17,3 \\
\hline Kamu Spotu & 172 & 21,1 \\
\hline Bayram, Özel Gün Kutlama, Başsağlığı, Anma & 42 & 5,2 \\
\hline Vatandaştan Fikir Alma, Anket & 5 & 0,6 \\
\hline Diğer Kurumlarla Etkileşim & 75 & 9,2 \\
\hline TOPLAM & $\mathbf{8 1 5}$ & $\mathbf{1 0 0 , 0}$ \\
\hline
\end{tabular}

Kaynak: Yazar tarafından hazırlanmıştır.

Grafik 1. Sağlık Bakanlığının Paylaştığı Tweetlerin Kodlar Arası Dağılımı

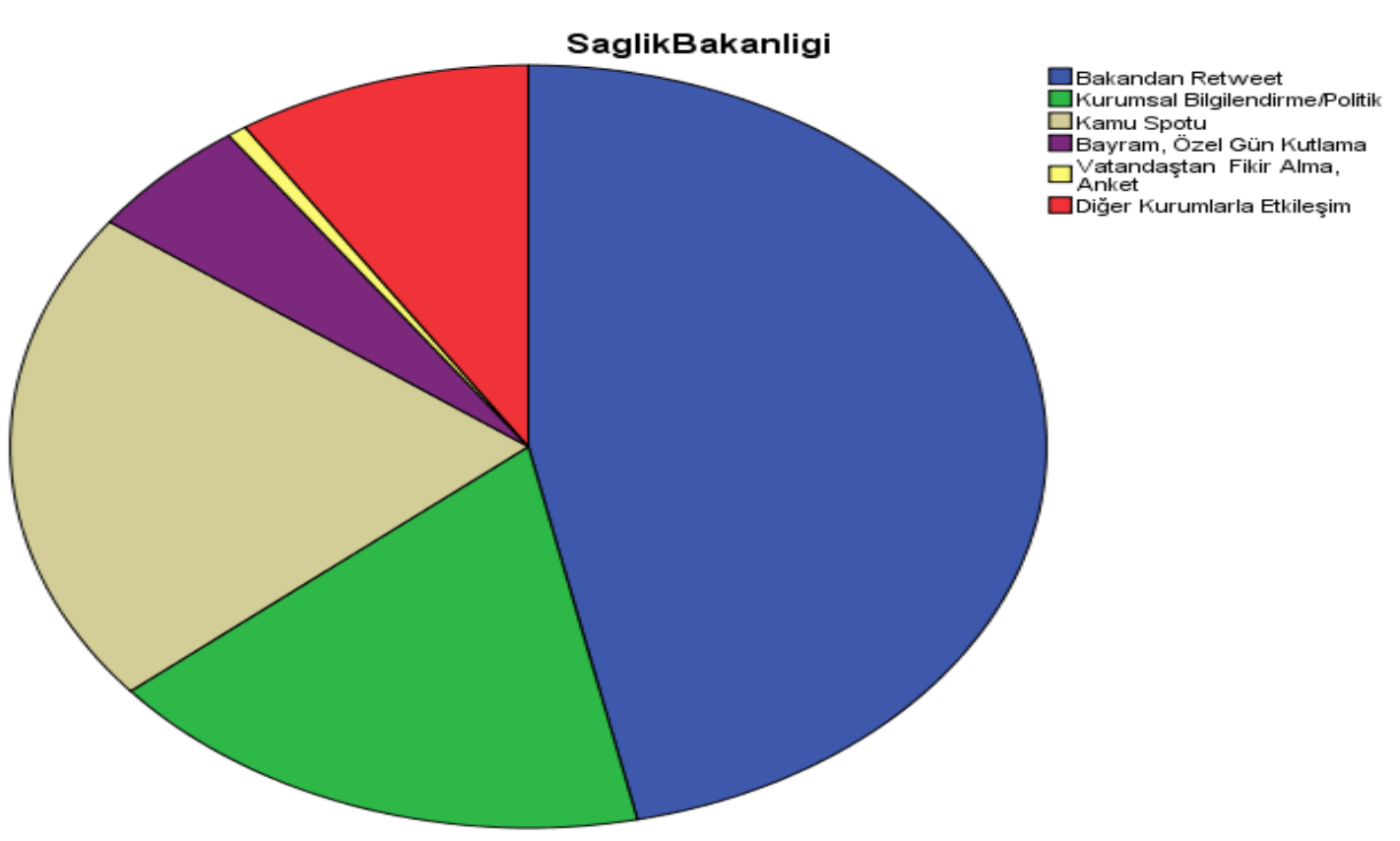

Kaynak: Yazar tarafından hazırlanmıştır.

Resmi Twitter hesabından en fazla tweet paylaşımında bulunan bakanlık olarak belirlenen sağlık bakanlığının paylaşmış olduğu tweetlerin kodlar içerisindeki dağılımı kayda değer şekilde çeşitlidir. Bakanlık, Twitter hesabından en fazla oranda ve sayıda kamu spotu paylaşan bakanlık olarak belirlenmiştir. Diğer yandan, bakanlığın vatandaştan fikir alma/anket ile ilgili tweet paylaşımı bir hayli düşük oranda olsa da, bu orana rağmen bakanlıklar arasında bu konuda en çok tweet paylaşan bakanlık olarak belirlenmiştir. Bakanlığın tweetleri en yüksek oranda "Bakandan Retweet" kodu içerisinde yer almıştır. 
Tablo 3. İçişleri Bakanlığının Paylaştığı Tweetlerin Kodlar Arası Dağılımı

\begin{tabular}{|c|c|c|}
\hline Kodlar & Tweet Sayısı & Oran (\%) \\
\hline Bakandan Retweet & 119 & 23,1 \\
\hline Kurumsal Bilgilendirme/ Politika Bildirimi & 290 & 56,2 \\
\hline Kamu Spotu & 16 & 3,1 \\
\hline Diğer Kurumlarla Etkileşim & 91 & 17,6 \\
\hline TOPLAM & $\mathbf{5 1 6}$ & $\mathbf{1 0 0 , 0}$ \\
\hline
\end{tabular}

Kaynak: Yazar tarafından hazırlanmıştır.

Grafik 2. İçişleri Bakanlığının Paylaştı̆̆ı Tweetlerin Kodlar Arası Dağılımı

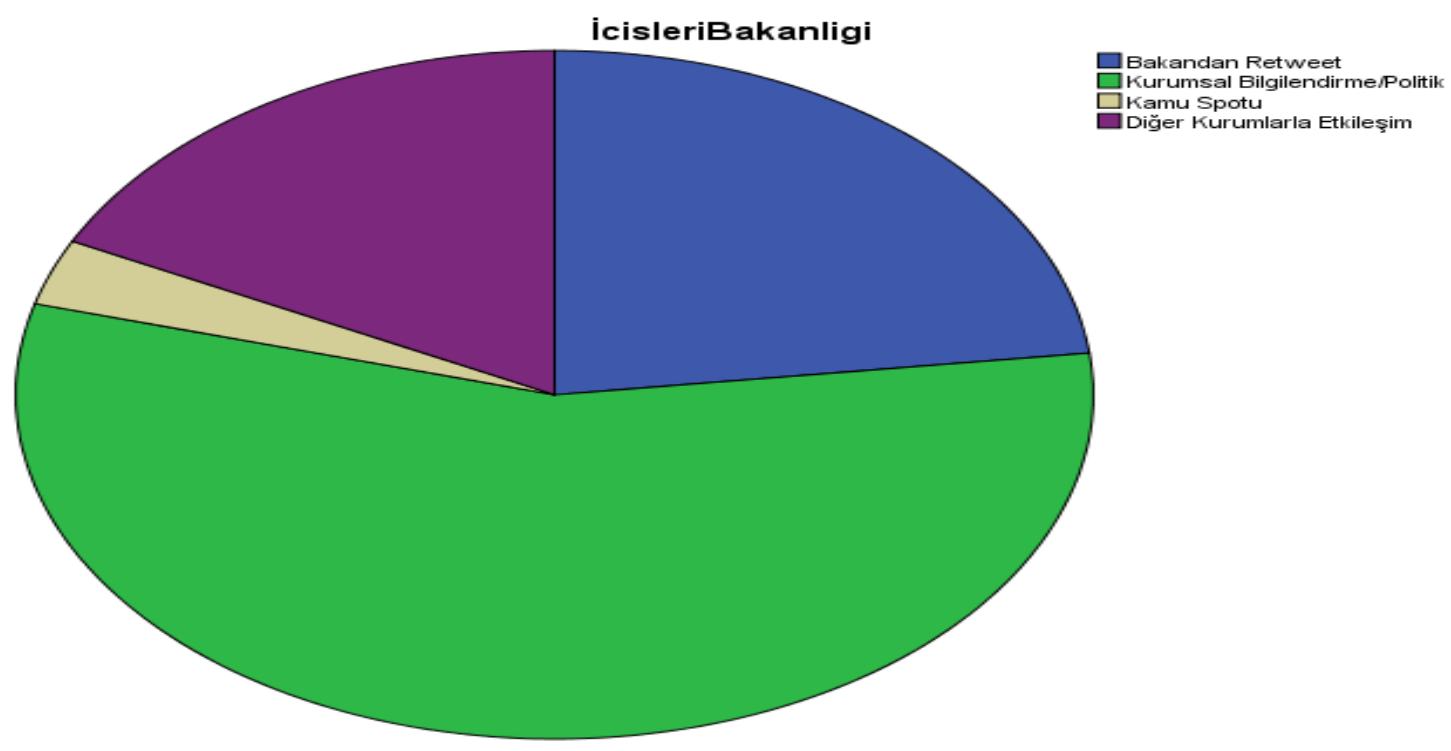

Kaynak: Yazar tarafindan hazırlanmıştır.

İçişleri Bakanlığının paylaştığı tweetler incelendiğinde, "Bayram, Özel Gün Kutlama, Başsă̆liğı, Anma” ile "Vatandaştan Fikir Alma, Anket" kodları kapsamına giren tweet atmadığı tespit edilmiştir. Her ne kadar "Bayram, Özel Gün Kutlama, Başsağlı̆̆l, Anma” kodu kapsamına giren tweet paylaşılmamış olsa da, bu kapsama giren tweetlerin bakandan yapılan retweetler aracılığıyla paylaşıldı ̆̆ belirlenmiştir. Bakanlıktan en yüksek oranda diğer kurumlarla etkileşimde bulunan tweetler paylaşılmıştır.

Tablo 4. Dışişleri Bakanlığının Paylaştığı Tweetlerin Kodlar Arası Dağılımı

\begin{tabular}{|c|c|c|}
\hline Kodlar & Tweet Sayısı & Oran (\%) \\
\hline Bakandan Retweet & 376 & 45,7 \\
\hline Kurumsal Bilgilendirme/Politika Bildirimi & 324 & 39,4 \\
\hline Bayram, Özel Gün Kutlama, Başsağlı̆̆ , Anma & 35 & 4,3 \\
\hline Diğer Kurumlarla Etkileşim & 88 & 10,7 \\
\hline TOPLAM & $\mathbf{8 2 3}$ & $\mathbf{1 0 0 , 0}$ \\
\hline
\end{tabular}

Kaynak: Yazar tarafından hazırlanmıştır. 
Grafik 3. Dışişleri Bakanlığının Paylaştığı Tweetlerin Kodlar Arası Dağılımı

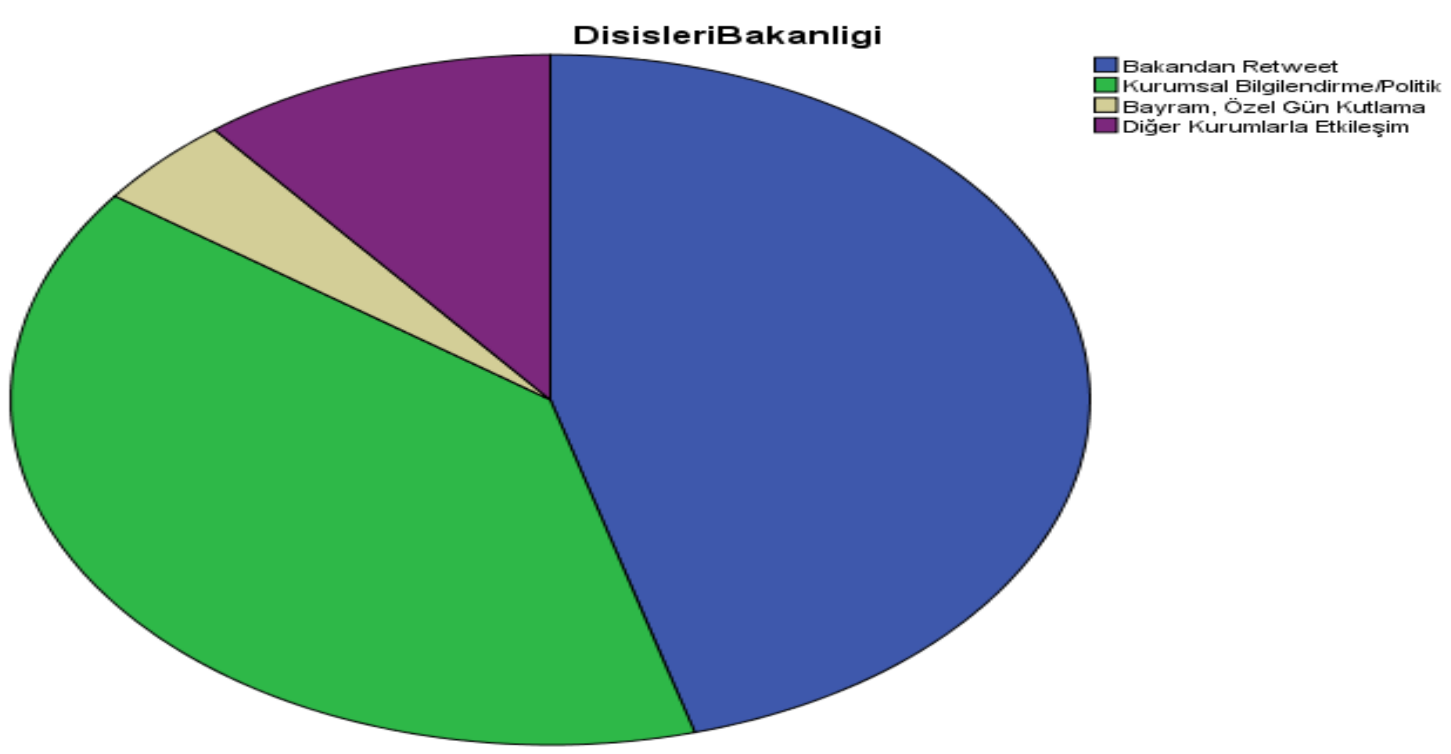

Kaynak: Yazar tarafindan hazırlanmıştır.

Twitter'ı paylaşılan tweet sayısı baz alındığında en aktif şekilde kullanan bakanlıklar arasında yer alan Dışişleri Bakanlığının paylaştığı twitlerin büyük çoğunluğu "Bakandan Retweet" ve "Kurumsal Bilgilendirme/Politika Bildirimi" kodları içerisinde dağılım göstermiştir. "Kamu Spotu" ve "Vatandaştan Fikir Alma. Anket" kodu içerisine giren tweet gözlemlenmezken, diğer tweetler ise "Diğer Kurumlarla Etkileşim" ve "Bayram, Özel Gün Kutlama, Başsağlığı, Anma” kodları arasında dağılmıştır.

Tablo 5. Gençlik ve Spor Bakanlığının Paylaştığı Tweetlerin Kodlar Arası Dağılımı

\begin{tabular}{|c|c|c|}
\hline Kodlar & Tweet Sayısı & Oran (\%) \\
\hline Bakandan Retweet & 117 & 26,4 \\
\hline Kurumsal Bilgilendirme/Politika bildirimi & 222 & 50,1 \\
\hline Kamu Spotu & 8 & 1,8 \\
\hline Bayram, Özel Gün Kutlama, Başsağlı̆̆ı, Anma & 90 & 20,3 \\
\hline Vatandaştan Fikir Alma, Anket & 1 & 1,1 \\
\hline Diğer Kurumlarla Etkileşim & 5 & $\mathbf{1 0 0 , 0}$ \\
\hline TOPLAM & $\mathbf{4 4 3}$ & \\
\hline
\end{tabular}

Kaynak: Yazar tarafından hazırlanmıştır. 
Grafik 4. Gençlik ve Spor Bakanlığının Paylaştığı Tweetlerin Kodlar Arası Dağılımı

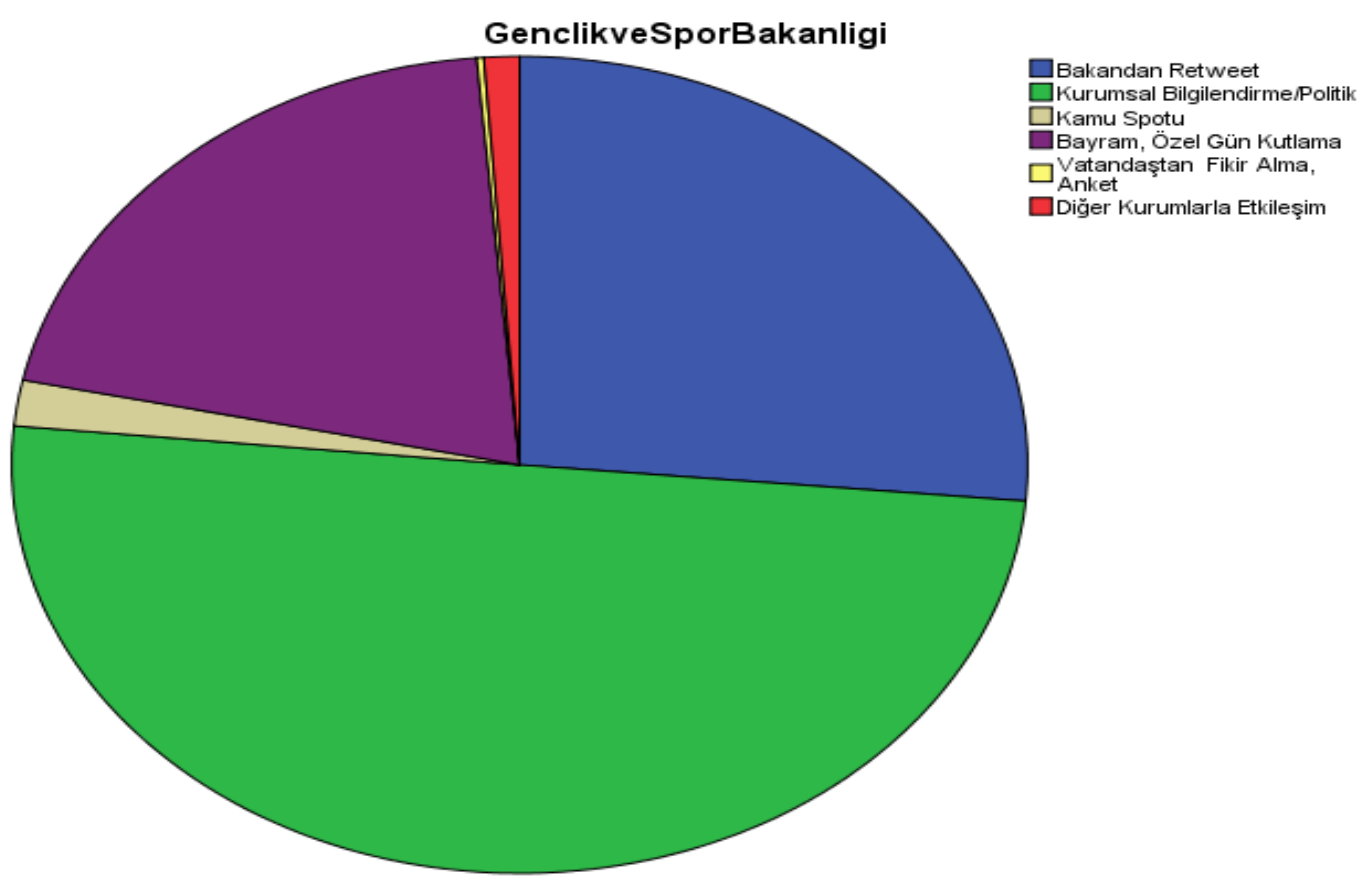

Kaynak: Yazar tarafından hazırlanmıştır.

Gençlik ve Spor Bakanlığı Twitter'da, en az sayıda diğer kurumlarla etkileşimde bulunan tweet paylaşan bakanlıklardan bir olarak belirlenmiştir. Bakanlık, "Bayram, Özel Gün Kutlama, Başsağlığı, Anma" kodu kapsamına giren tweet oranının fazlalığıyla öne çıkmaktadır. Bunun sebebi, kurumun her branştan belirli başarılar göstermiş sporcular için paylaştığ 1 kutlama ve tebrik tweetleridir. Bakanlık kamu spotu içeren tweetler ve bir de vatandaş katılımına yönelik tweet paylaşmıştır.

Tablo 6. Ulaştırma ve Altyapı Bakanlı̆̆ının Paylaştığı Tweetlerin Kodlar Arası Dağılımı

\begin{tabular}{|c|c|c|}
\hline Kodlar & Tweet Sayısı & Oran (\%) \\
\hline Bakandan Retweet & 82 & 10,1 \\
\hline Kurumsal Bilgilendirme/Politika Bildirimi & 560 & 69,1 \\
\hline Kamu Spotu & 29 & 3,6 \\
\hline Bayram, Özel Gün Kutlama, Başsağlı̆̆ , Anma & 39 & 4,8 \\
\hline Diğer Kurumlarla Etkileşim & 101 & 12,5 \\
\hline TOPLAM & $\mathbf{8 1 1}$ & $\mathbf{1 0 0 , 0}$ \\
\hline
\end{tabular}

Kaynak: Yazar tarafından hazırlanmıştır. 
Grafik 5. Ulaştırma ve Altyapı Bakanlığının Paylaştığı Tweetlerin Kodlar Arası Dağılımı

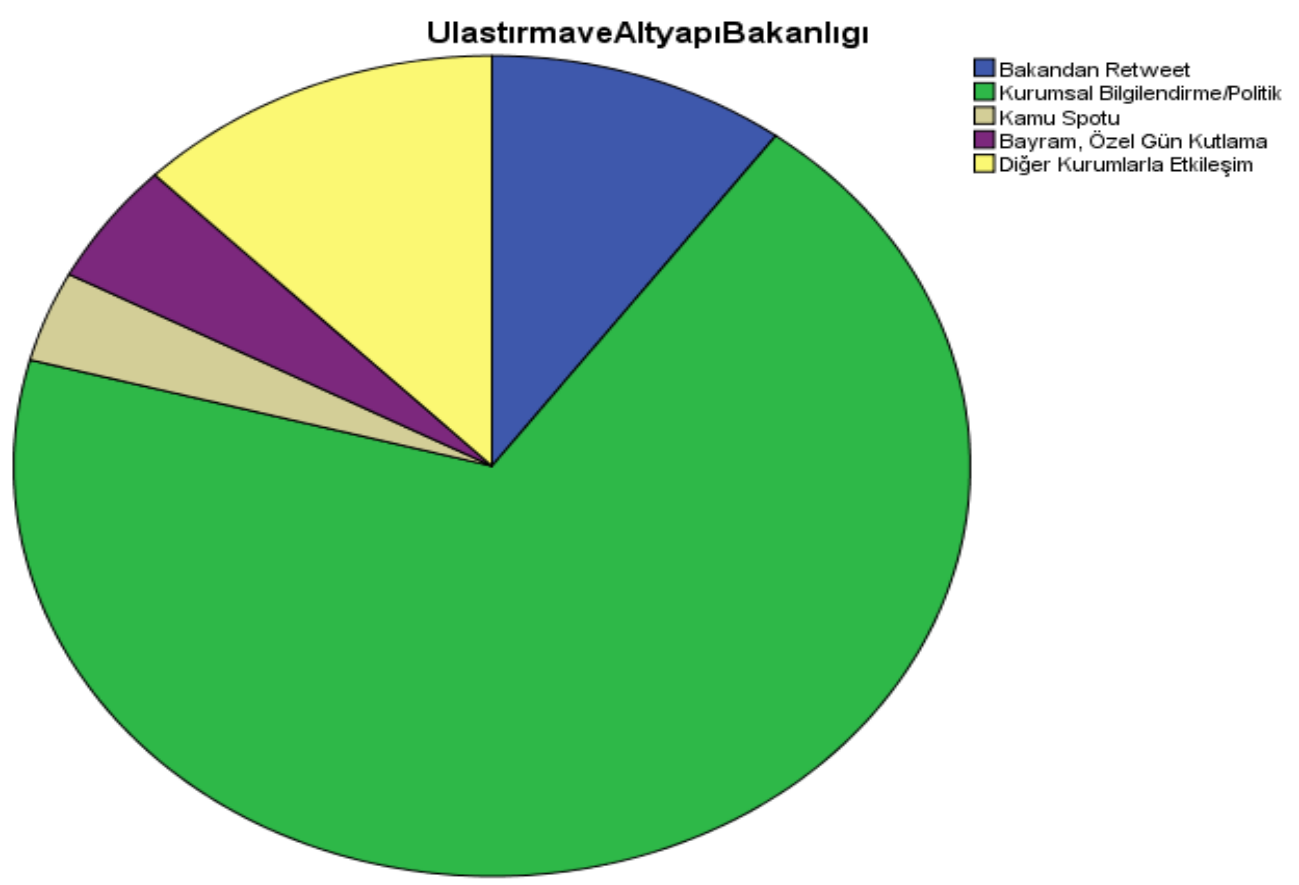

Kaynak: Yazar tarafından hazırlanmıştır.

Ulaştırma ve Altyapı Bakanlığının paylaştığı tweetlerin büyük bir çoğunluğunun "Kurumsal Bilgilendirme/Politika Bildirimi” kodu kapsamına girdiği belirlenmiştir. Bu tweetlerde daha çok yol yapım ve ulaştırma hizmetlerinde gerçekleştirilen icraatlar konu edilmiştir. Diğer bakanlıklara oranla bu bakanlıkta paylaşılan kamu spotu içerikli tweetler daha fazladır. Trafik kuralları ve trafik kazalarına karşı vatandaşların uyarımı, bu tweetlerin odak aldığı başlıca konulardır. Dikkat çeken başka bir bulgu ise bakanlığın bakandan retweet ederek paylaştığı tweetlerin oranının diğer bakanlıklara göre bir hayli düşük olmasıdır.

Tablo 7. Milli Eğitim Bakanlığının Paylaştığı Tweetlerin Kodlar Arası Dağılımı

\begin{tabular}{|c|c|c|}
\hline Kodlar & Tweet Sayısı & Oran (\%) \\
\hline Bakandan Retweet & 53 & 11,7 \\
\hline Kurumsal Bilgilendirme/Politika Bildirimi & 356 & 78,6 \\
\hline Kamu Spotu & 10 & 2,2 \\
\hline Bayram, Özel Gün Kutlama, Başsağlı̆̆ , Anma & 6 & 1,3 \\
\hline Diğer Kurumlarla Etkileşim & 28 & 6,2 \\
\hline TOPLAM & $\mathbf{4 5 3}$ & $\mathbf{1 0 0 , 0}$ \\
\hline
\end{tabular}

Kaynak: Yazar tarafından hazırlanmıştır. 
Grafik 6. Milli Eğitim Bakanlığının Paylaştığı Tweetlerin Kodlar Arası Dağılımı

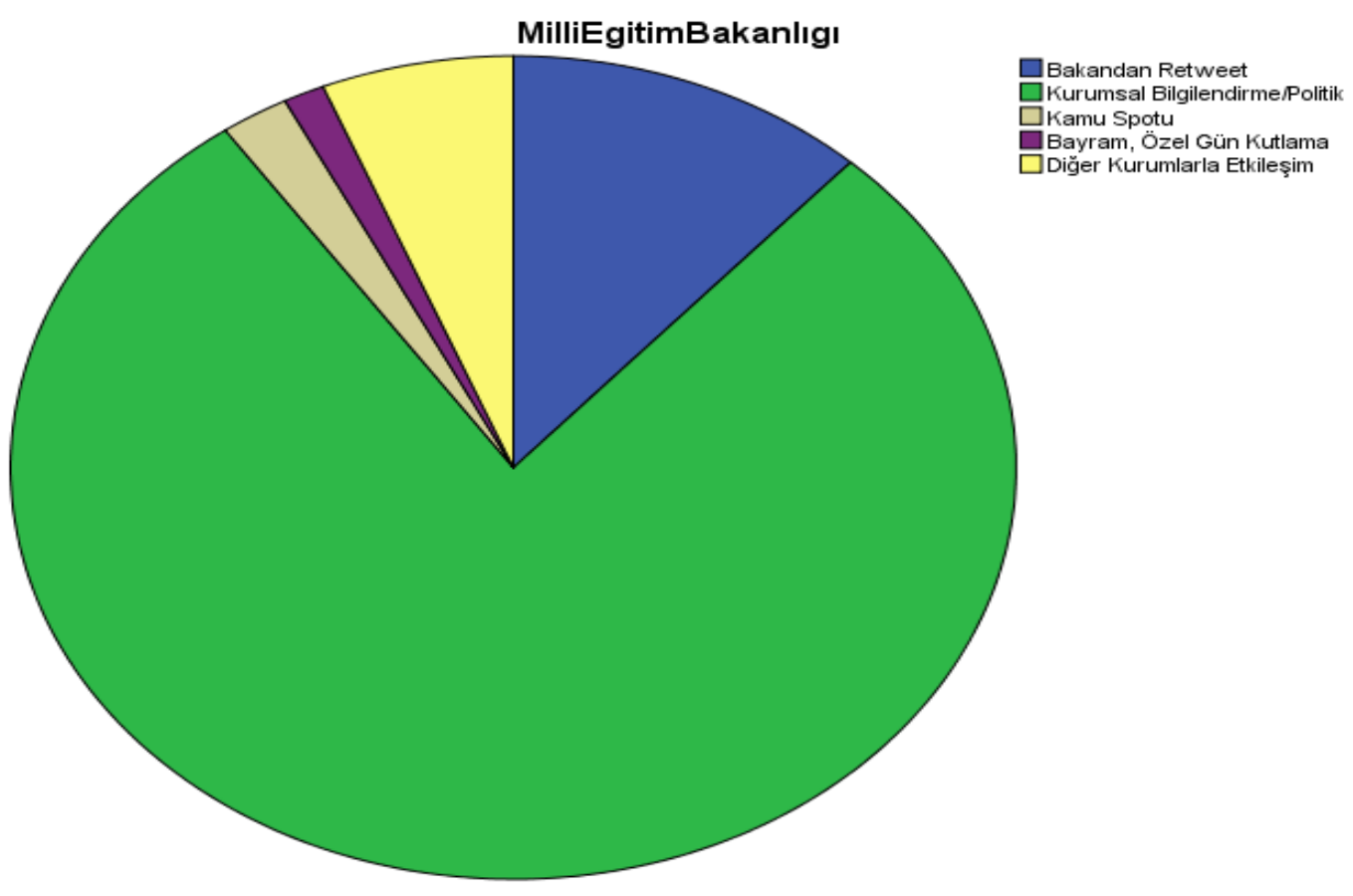

Kaynak: Yazar tarafından hazırlanmıştır.

Milli Eğitim Bakanlığının paylaştığı tweetlerin çok büyük bir oranı "Kurumsal Bilgilendirme/Politika Bildirimi”" kodu içerisinde konumlandırılmıştır. Bu tweetlerde daha çok bakanın programı, yaptığı ziyaretler, icraatlar, katıldığı toplantılar paylaşılmıştır. Bunların yanında tweetlerde düşük oranda da olsa kamu spotlarına yer verilmiştir. Bakandan yapılan retweetlerin oranı diğer bakanlıklara kıyasla düşüktür.

Tablo 8. Milli Savunma Bakanlığının Paylaştı̆̆ Tweetlerin Kodlar Arası Dağılımı

\begin{tabular}{|c|c|c|}
\hline Kodlar & Tweet Sayısı & Oran (\%) \\
\hline Kurumsal Bilgilendirme/Politika Bildirimi & 729 & 91,9 \\
\hline Kamu Spotu & 5 &, 6 \\
\hline Bayram, Özel Gün Kutlama, Başsağlığı, Anma & 55 & 6,9 \\
\hline Diğer Kurumlarla Etkileşim & 4 &, 5 \\
\hline TOPLAM & $\mathbf{7 9 3}$ & $\mathbf{1 0 0 , 0}$ \\
\hline
\end{tabular}

Kaynak: Yazar tarafından hazırlanmıştır. 
Grafik 7. Milli Savunma Bakanlığının Paylaştığı Tweetlerin Kodlar Arası Dağılımı

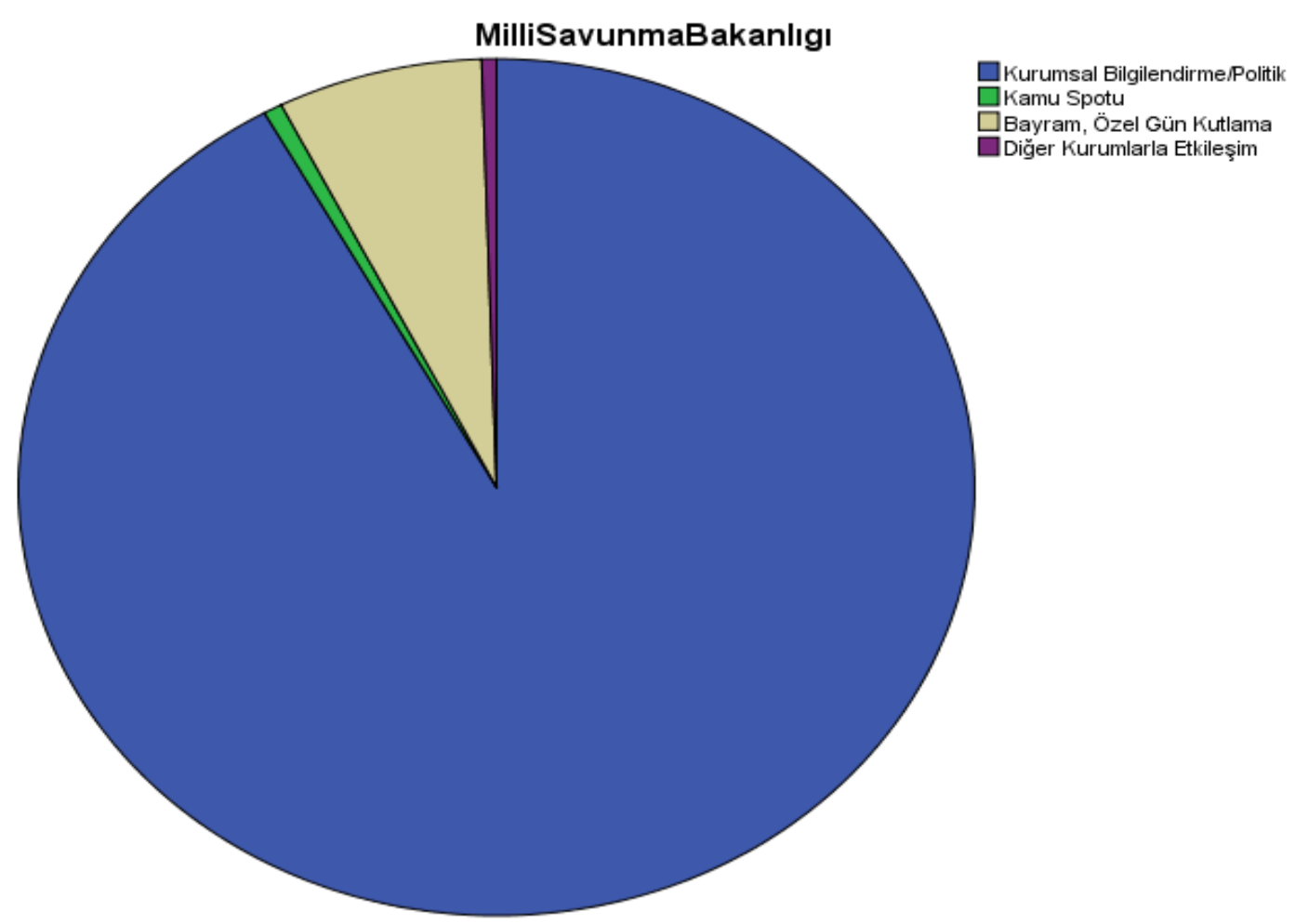

Kaynak: Yazar tarafından hazırlanmıştır.

Milli Savunma Bakanlığı da paylaştığı tweet sayısı baz alındığında, Twitter'ı en aktif şekilde kullanan bakanlıklardan birisi olarak belirlenmiştir. Bakanlığın paylaştığı tweetlerin çok büyük bir bölümü "Kurumsal Bilgilendirme/Politika Bildirimi" kodu içerisinde yer almıştır. Söz konusu tweetlerde özellikle terörle mücadele kapsamında yapılan operasyonların kurumsal olarak kamuoyuna bildirilmiştir. Bunun dışında, araştırmanın yapıldığı dönemde ülke gündeminde olan "Rusya'dan S-400 hava savunma sistemlerinin alınması" konusuna odaklanan kurumsal ve politik bildirimler paylaşılmıştır. Bakanlığın paylaştığı tweetlerde bakandan retweet olarak paylaşılan hiç tweet bulunmaması, bakanlığın Twitter kullanımında diğer bakanlıklardan farklılaşan en büyük özelliğidir. Kayda değer bir oranda paylaşılan ve "Bayram, Özel Gün Kutlama, Başsağlığı, Anma" kodu içerisinde gruplandırılan tweetlerin önemli bir kısmı ise şehitlere başsağlı̆̆ ve anma amacı ile paylaşılmıştır.

Tablo 9. Ticaret Bakanlığının Paylaştığı Tweetlerin Kodlar Arası Dağılımı

\begin{tabular}{|c|c|c|}
\hline Kodlar & Tweet Sayısı & Oran (\%) \\
\hline Bakandan Retweet & 24 & 8,7 \\
\hline Kurumsal Bilgilendirme/Politika Bildirimi & 180 & 65,2 \\
\hline Kamu Spotu & 12 & 4,3 \\
\hline Bayram, Özel Gün Kutlama, Başsağlı̆̆ı, Anma & 6 & 2,2 \\
\hline Diğer Kurumlarla Etkileşim & 54 & 19,6 \\
\hline TOPLAM & $\mathbf{2 7 6}$ & $\mathbf{1 0 0 , 0}$ \\
\hline
\end{tabular}

Kaynak: Yazar tarafından hazırlanmıştır. 
Grafik 8. Ticaret Bakanlığının Paylaştığı Tweetlerin Kodlar Arası Dağılımı

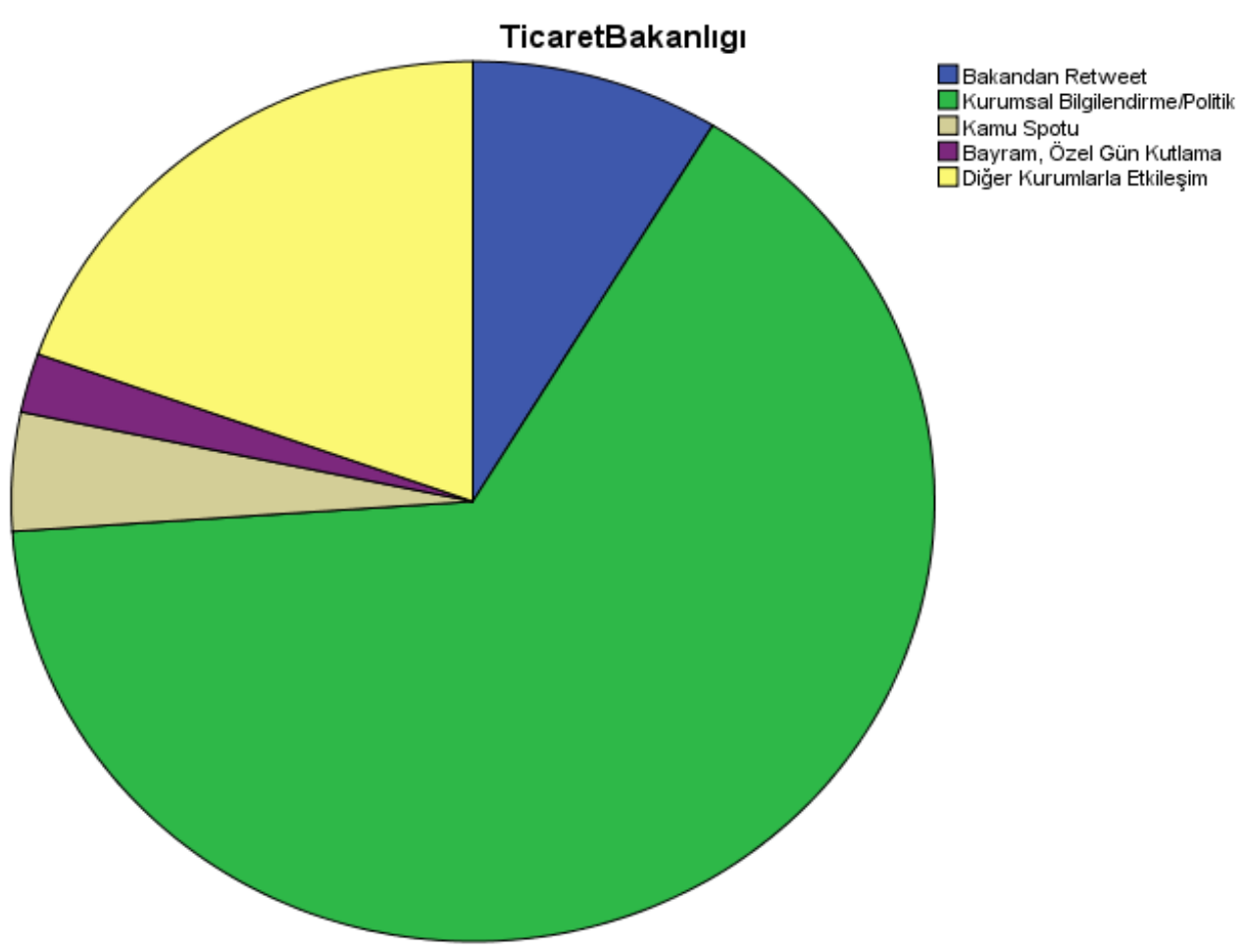

Kaynak: Yazar tarafindan hazırlanmıştır.

Ticaret Bakanlığının paylaştığı tweetlere bakıldığında, tweetlerin büyük oranda "Kurumsal Bilgilendirme/Politika Bildirimi" kodu içerisinde yer aldığı belirlenmiştir. Bunun yanında bakanlık diğer kurumlarla da kayda değer bir oranda etkileşimde bulunmuştur. Bakanlık aynı zamanda en fazla kamu spotu içeren tweet paylaşan bakanlıklardan biri olarak belirlenmiştir.

Tablo 10. Hazine ve Maliye Bakanlığının Paylaştığı Tweetlerin Kodlar Arası Dağılımı

\begin{tabular}{|c|c|c|}
\hline Kodlar & Tweet Sayısı & Oran (\%) \\
\hline Bakandan Retweet & 16 & 19,5 \\
\hline Kurumsal Bilgilendirme/Politika Bildirimi & 59 & 72,0 \\
\hline Bayram, Özel Gün Kutlama, Başsağlı̆̆ı, Anma & 6 & 7,3 \\
\hline Diğer Kurumlarla Etkileşim & 1 & 1,2 \\
\hline TOPLAM & $\mathbf{8 2}$ & $\mathbf{1 0 0 , 0}$ \\
\hline
\end{tabular}

Kaynak: Yazar tarafından hazırlanmıştır. 
Grafik 9. Hazine ve Maliye Bakanlığının Paylaştığı Tweetlerin Kodlar Arası Dağılımı

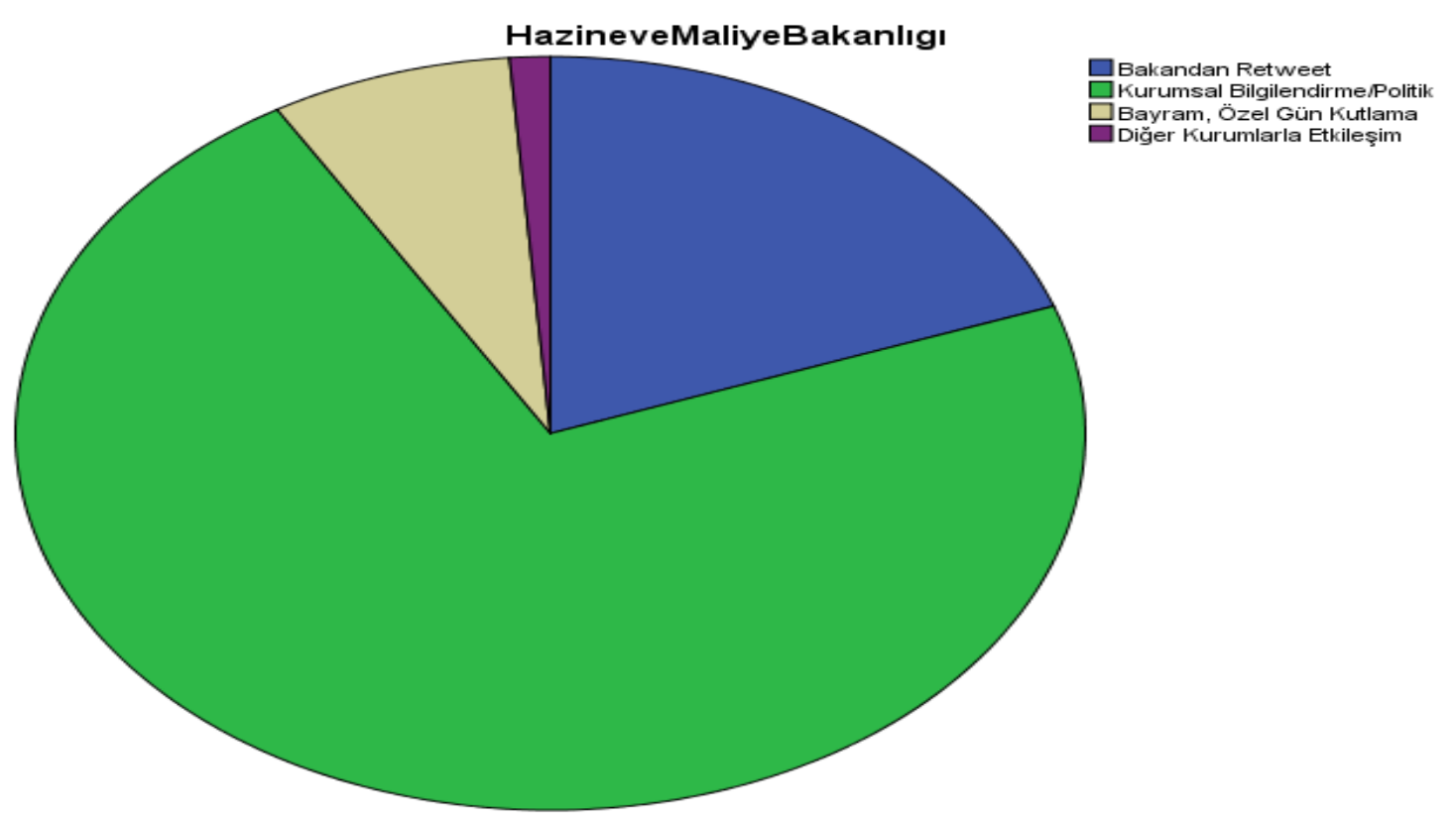

Kaynak: Yazar tarafından hazırlanmıştır.

Twitter'da 2019 yılında paylaştığı tweet sayısı bakımından en az aktif olan bakanlık Hazine ve Maliye Bakanlığı olarak belirlenmiştir. Tweetlerin büyük bir çoğunluğu "Kurumsal Bilgilendirme/Politika Bildirimi" kodu içerisinde yer almıştır. Kamu spotu ya da vatandaştan fikir alan nitelikte tweet paylaşılmamış olup, bakandan retweet dışında kalan kodlarda dağılan tweetlerin oranı her biri için \%10’un altında kalmıştır.

Tablo 11. Enerji ve Tabii Kaynaklar Bakanlığının Paylaştığı Tweetlerin Kodlar Arası Dağılımı

\begin{tabular}{|c|c|c|}
\hline Kodlar & Tweet Sayısı & Oran (\%) \\
\hline Bakandan Retweet & 20 & 9,4 \\
\hline Kurumsal Bilgilendirme/Politika Bildirimi & 154 & 72,3 \\
\hline Kamu Spotu & 9 & 4,2 \\
\hline Bayram, Özel Gün Kutlama, Başsağlığı, Anma & 11 & 5,2 \\
\hline Diğer Kurumlarla Etkileşim & 19 & 8,9 \\
\hline TOPLAM & $\mathbf{2 1 3}$ & $\mathbf{1 0 0 , 0}$ \\
\hline
\end{tabular}

Kaynak: Yazar tarafından hazırlanmıştır. 
Grafik 10. Enerji ve Tabii Kaynaklar Bakanlığının Paylaştı̆̆ı Tweetlerin Kodlar Arası Dağılımı

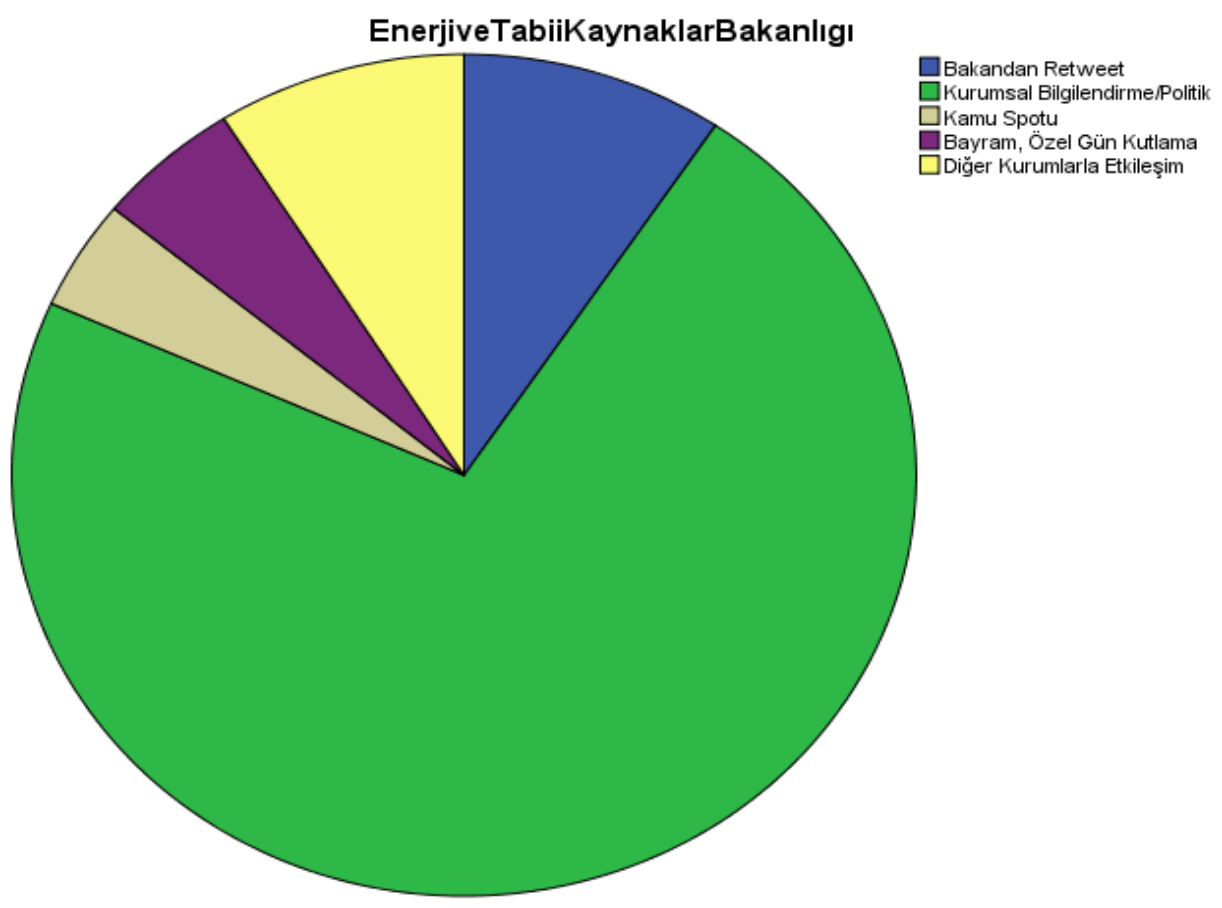

Kaynak: Yazar tarafindan hazırlanmıştır.

Enerji ve Tabii Kaynaklar Bakanlığının paylaştığı tweetlerin büyük bir oranı "Kurumsal Bilgilendirme/Politika Bildirimi” kodu içerisinde yer almıştır. Vatandaştan fikir almaya ilişkin tweetlere rastlanmamıştır. Bakanlığın paylaştı̆̆ diğer tweetler ise geriye kalan kodlar arasında her bir kod için \%10 oranının altına olmak üzere neredeyse homojen bir şekilde dağılım göstermiştir.

Tablo 12. Adalet Bakanlığının Paylaştığı Tweetlerin Kodlar Arası Dağılımı

\begin{tabular}{|c|c|c|}
\hline Kodlar & Tweet Sayısı & Oran (\%) \\
\hline Bakandan Retweet & 9 & 4,6 \\
\hline Kurumsal Bilgilendirme/Politika Bildirimi & 161 & 83,0 \\
\hline Kamu Spotu & 3 & 1,5 \\
\hline Bayram, Özel Gün Kutlama, Başsağlığı, Anma & 9 & 4,6 \\
\hline Diğer Kurumlarla Etkileşim & 12 & 6,2 \\
\hline TOPLAM & $\mathbf{1 9 4}$ & $\mathbf{1 0 0 , 0}$ \\
\hline
\end{tabular}

Kaynak: Yazar tarafından hazırlanmıştır. 
Grafik 11. Adalet Bakanlığının Paylaştı̆̆ı Tweetlerin Kodlar Arası Dağılımı

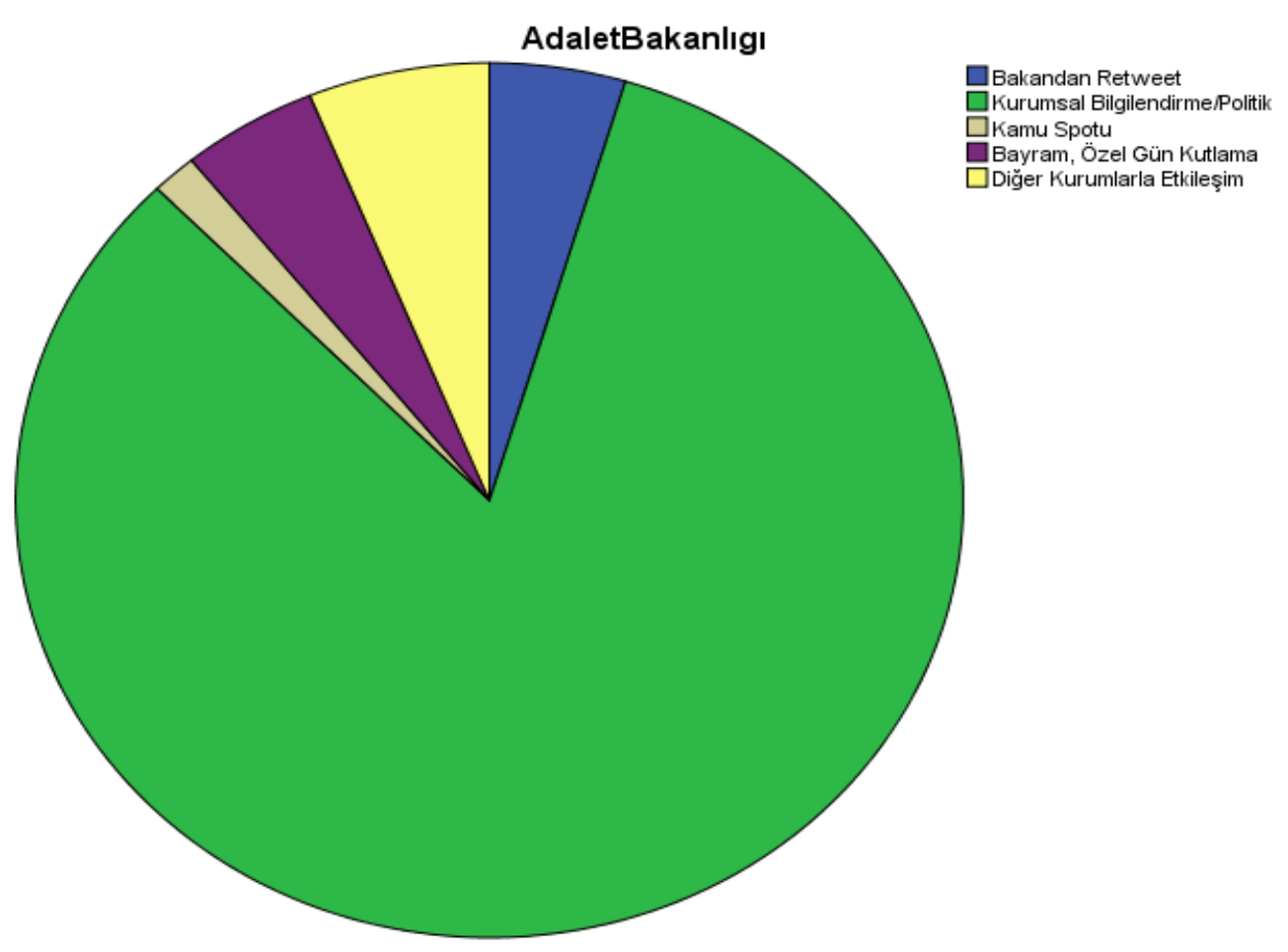

Kaynak: Yazar tarafindan hazırlanmıştır.

Adalet Bakanlığı tarafindan Twitter'da paylaşılan tweetlerin büyük oranı "Kurumsal Bilgilendirme/Politika Bildirimi" kodu içerisinde kendine yer bulmuştur. Bakanlığı, sosyal medya kullanımı konusunda diğer bakanlıklardan ayıran en büyük özellik, kurum bünyesinde bulunan müdürlükler ve özellikle daire başkanlıklarının da kendilerine ait aktif kullanılan resmi Twitter hesaplaırnın olmasıdır. Bakanlık bazı tweetleri kendi resmi hesabından paylaşmak yerine, söz konusu alt birimlerin Twitter hesaplarından paylaşılan tweetleri retweet etmek suretiyle paylaşmaktadır. Araştırmada bu alt birimlerin paylaştıkları tweetlerin bakanlık tarafından retweet edilmesi, araştırmanın yönteminde de belirtildiği üzere "Diğer Kurumlarla Etkileşim" kodu içerisinde değerlendirilmemiştir. Bu yüzden söz konusu koda ait oran düşük kalmıştır.

Tablo 13. Tarım ve Orman Bakanlığının Paylaştığı Tweetlerin Kodlar Arası Dağılımı

\begin{tabular}{|c|c|c|}
\hline Kodlar & Tweet Sayısı & Oran (\%) \\
\hline Bakandan Retweet & 34 & 4,1 \\
\hline Kurumsal Bilgilendirme/Politika Bildirimi & 752 & 89,7 \\
\hline Kamu Spotu & 10 & 1,2 \\
\hline Bayram, Özel Gün Kutlama, Başsağlığı, Anma & 27 & 3,2 \\
\hline Diğer Kurumlarla Etkileşim & 15 & 1,8 \\
\hline TOPLAM & $\mathbf{8 3 8}$ & $\mathbf{1 0 0 , 0}$ \\
\hline
\end{tabular}

Kaynak: Yazar tarafından hazırlanmıştır. 
Grafik 12. Tarım ve Orman Bakanlığının Paylaştığı Tweetlerin Kodlar Arası Dağılımı

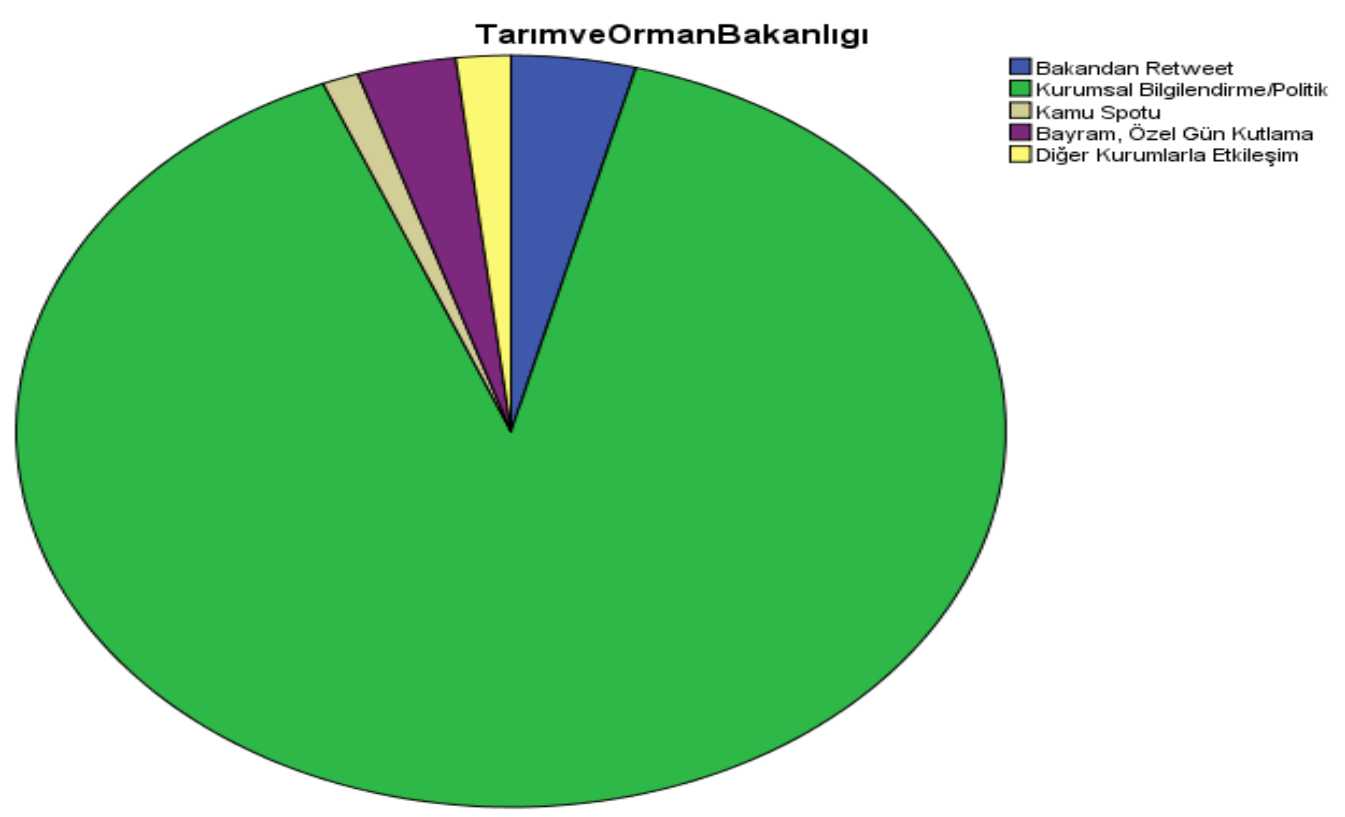

Kaynak: Yazar tarafından hazırlanmıştır.

Tarım ve Orman Bakanlığı da paylaştığı tweet sayısı göz önüne alındığında Twitter'da en aktif bakanlıklar arasında yerini almıştır. Bakanlığın paylaştığı tweetlerin büyük bir çoğunluğu "Kurumsal Bilgilendirme/Politika Bildirimi" kodu altında konumlanmıştır. Diğer tweetler ise "Vatandaştan Fikir Alma/Anket" kodu dışındaki diğer kodlar arasında $\% 5$ oranından düşük olmak suretiyle dağılmışlardır.

Tablo 14. Sanayi ve Teknoloji Bakanlığının Paylaştı̆̆ı Tweetlerin Kodlar Arası Dağılımı

\begin{tabular}{|c|c|c|}
\hline Kodlar & Tweet Sayısı & Oran (\%) \\
\hline Bakandan Retweet & 94 & 16,6 \\
\hline Kurumsal Bilgilendirme/Politika Bildirimi & 246 & 43,4 \\
\hline Bayram, Özel Gün Kutlama, Başsağlı̆̆ı, Anma & 9 & 1,6 \\
\hline Vatandaştan Fikir Alma, Anket & 1 &, 2 \\
\hline Diğer Kurumlarla Etkileşim & 217 & 38,3 \\
\hline TOPLAM & $\mathbf{5 6 7}$ & $\mathbf{1 0 0 , 0}$ \\
\hline
\end{tabular}

Kaynak: Yazar tarafından hazırlanmıştır. 
Grafik 13. Sanayi ve Teknoloji Bakanlığının Paylaştığı Tweetlerin Kodlar Arası Dağılımı

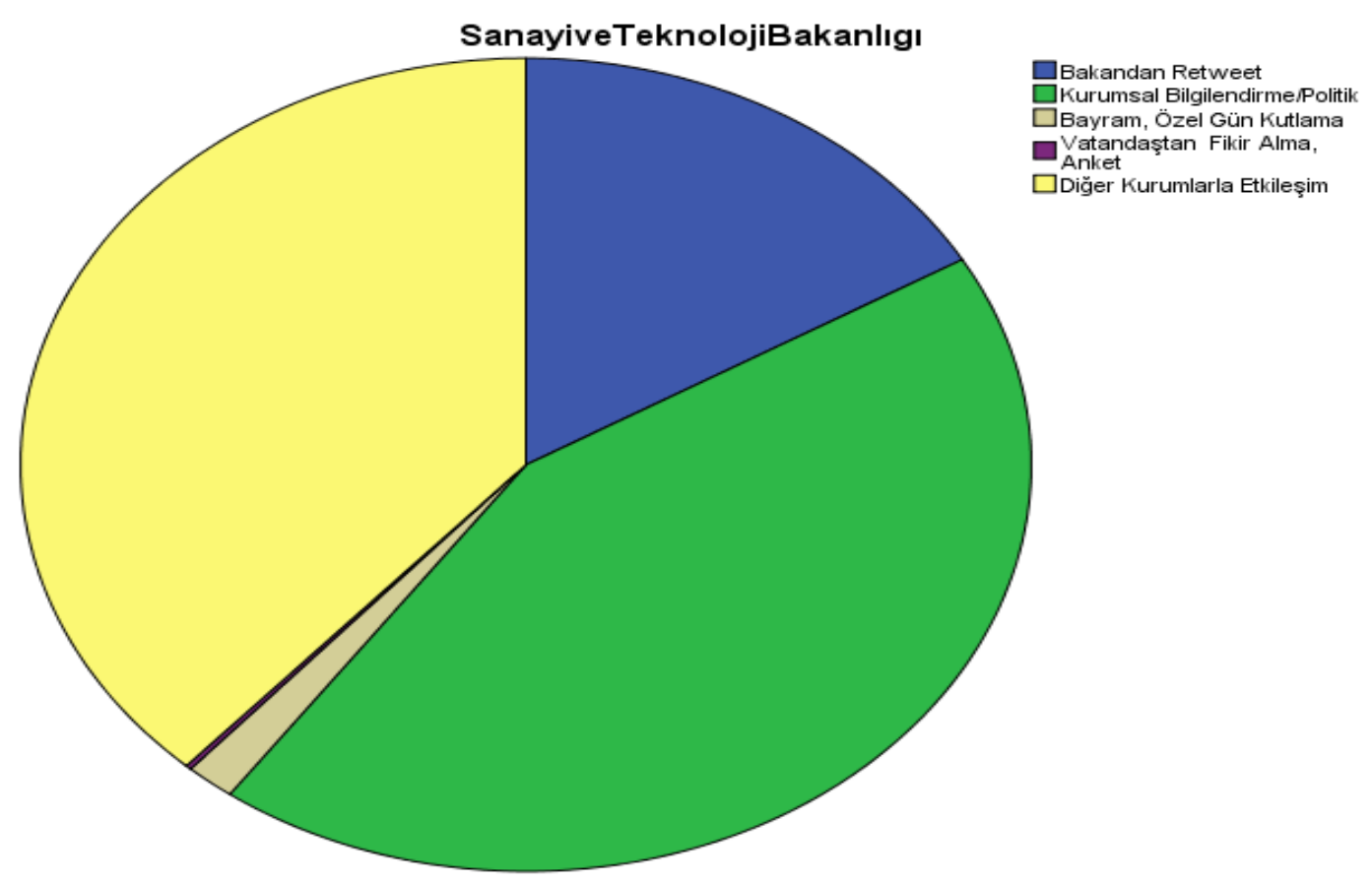

Kaynak: Yazar tarafindan hazırlanmıştır.

Sanayi ve Teknoloji Bakanlığının tweetleri incelendiğinde tweetler en yüksek oranda "Kurumsal Bilgilendirme/Politika Bildirimi" ve "Diğer Kurumlarla Etkileşim" kodları arasında dağılım gösterdiği tespit edilmiştir. Tweetlerin önemli bir bölümü de "Bakandan Retweet" kodu içerisinde yer almıştır. Bakanlığın vatandaştan fikir almaya yönelik de bir tweet tespit edilmiştir. Bayram özel gün kutlamaya yönelik tweetler genel olarak bakandan retweet edilmiştir.

Tablo 15. Aile, Çalışma ve Sosyal Hizmetler Bakanlığının Paylaştı̆̆ı Tweetlerin Kodlar Arası Dağılımı

\begin{tabular}{|c|c|c|}
\hline Kodlar & Tweet Sayısı & Oran (\%) \\
\hline Bakandan Retweet & 267 & 33,5 \\
\hline Kurumsal Bilgilendirme/Politika Bildirimi & 218 & 27,4 \\
\hline Kamu Spotu & 1 &, 1 \\
\hline Bayram, Özel Gün Kutlama, Başsağlı̆̆ Anma & 3 &, 4 \\
\hline Diğer Kurumlarla Etkileşim & 308 & 38,6 \\
\hline TOPLAM & $\mathbf{7 9 7}$ & $\mathbf{1 0 0 , 0}$ \\
\hline
\end{tabular}

Kaynak: Yazar tarafından hazırlanmıştır. 
Grafik 14. Aile, Çalışma ve Sosyal Hizmetler Bakanlığının Paylaştı̆̆ı Tweetlerin Kodlar Arası Dağılımı

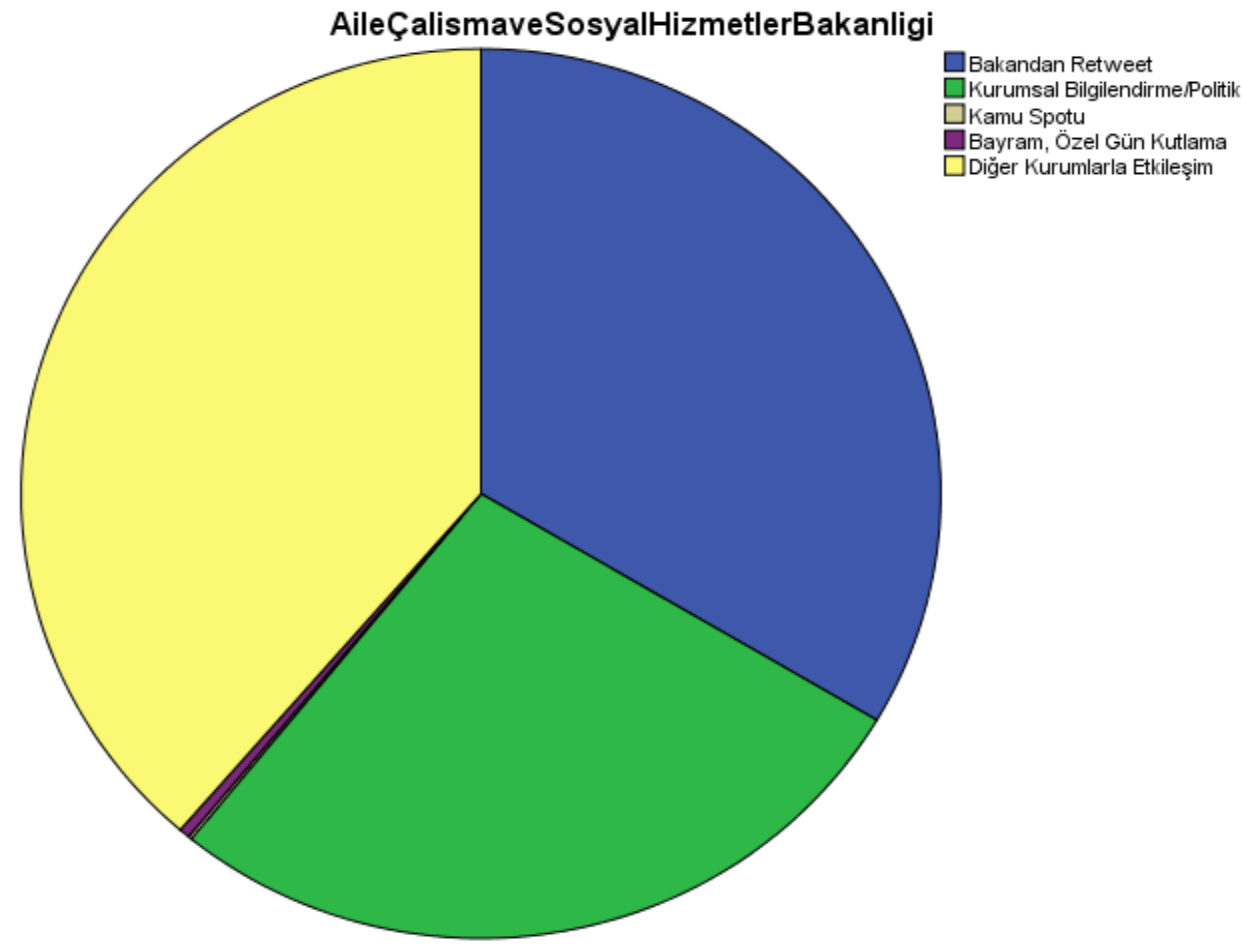

Kaynak: Yazar tarafindan hazırlanmıştır.

Aile, Çalışma ve Sosyal Hizmetler Bakanlığının paylaştığı tweetler de diğer bakanlıklarda genel olarak gözlemlenen "Bakandan Retweet", "Kurumsal Bilgilendirme/Politika Bildirimi", ve "Diğer Kurumlarla Etkileşim" kodları arasında dağılım göstermiştir. Bakanlığı diğer bakanlıklardan ayıran en büyük farklılık, "Bayram, Özel Gün Kutlama" tweetlerinin kurumun kendi hesabından yazılarak paylaşılmaması, bunun yerine diğer kurumların (söz konusu bakanlığa bağlı ya da bağlı olmayan ancak araştırmada belirtilen kapsam dışında kalan) paylaştıkları bayram, özel gün kutlama tweetlerinin retweet edilmesidir. Bu yüzden araştırmada Aile, Çalışma ve Sosyal Hizmetler Bakanlığının bu kod içerisinde dağılım gösteren tweet sayısı bir hayli düşük kalmıştır.

Tablo 16. Çevre ve Şehircilik Bakanlığının Paylaştığı Tweetlerin Kodlar Arası Dă̆ı̆ımı

\begin{tabular}{|c|c|c|}
\hline Kodlar & Tweet Sayısı & Oran (\%) \\
\hline Bakandan Retweet & 114 & 19,3 \\
\hline Kurumsal Bilgilendirme/Politika Bildirimi & 456 & 77,0 \\
\hline Kamu Spotu & 1 &, 2 \\
\hline Bayram, Özel Gün Kutlama, Başsağlı̆̆ Anma & 2 & 3 \\
\hline Diğer Kurumlarla Etkileşim & 19 & 3,2 \\
\hline TOPLAM & $\mathbf{5 9 2}$ & $\mathbf{1 0 0 , 0}$ \\
\hline
\end{tabular}

Kaynak: Yazar tarafından hazırlanmıştır. 
Grafik 15. Çevre ve Şehircilik Bakanlığının Paylaştığı Tweetlerin Kodlar Arası Dağılımı

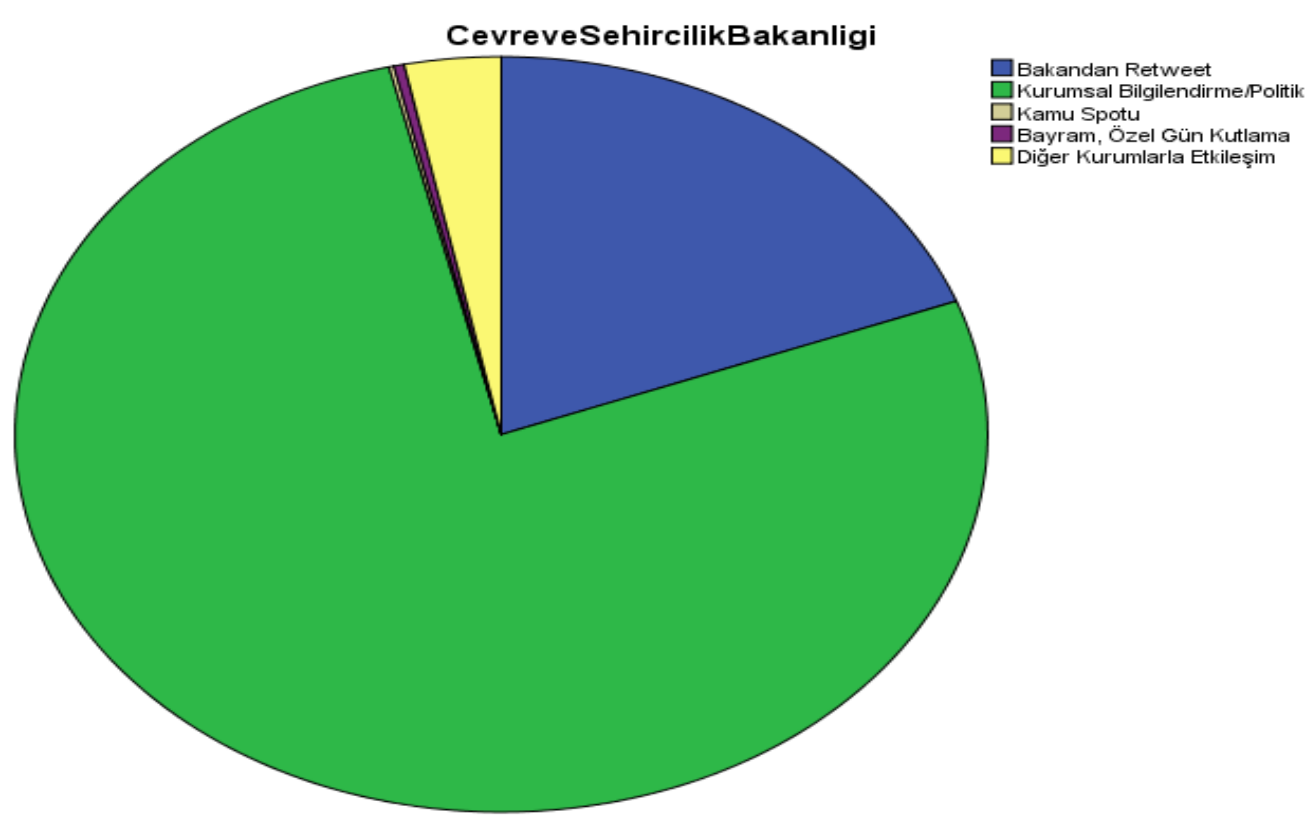

Kaynak: Yazar tarafından hazırlanmıştır.

Çevre ve Şehircilik Bakanlığı tarafindan paylaşılan tweetler analiz edildiğinde, söz konusu tweetlerin büyük oranda "Kurumsal Bilgilendirme/Politika Bildirimi" kodu içersinde bulunduğu, tespit edilmiştir. Bunlar dışında kalan tweetlerin büyük oranı da "Bakandan Retweet" kodu içerisinde dağılım göstermiştir. Bu bakanlıkta da Aile, Çalışma ve Sosyal Hizmetler Bakanlığında bir yönüyle farklılaşarak, tebrik, başsağlığı ve anma temasında paylaşılan tweetler çoğunlukla bakanın şahsi Twitter hesabından paylaştı̆̆ı aynı temalı tweetlerin retweet yapılması suretiyle paylaşılmıştır. Bu yüzden söz konusu kod içerisinde yer bulan tweetlerin sayısı bir hayli azdır. Bakanlığın diğer kurumlarla etkileşimde bulunarak paylaştığı tweetlerin oranı da görece azdır.

Tablo 17. Kültür ve Turizm Bakanlığının Paylaştığı Tweetlerin Kodlar Arası Dağılımı

\begin{tabular}{|c|c|c|}
\hline Kodlar & Tweet Sayısı & Oran (\%) \\
\hline Bakandan Retweet & 218 & 32,5 \\
\hline $\begin{array}{c}\text { Kurumsal Bilgilendirme/Politika } \\
\text { Bildirimi }\end{array}$ & 285 & 42,5 \\
\hline Kamu Spotu & 1 &, 1 \\
\hline $\begin{array}{c}\text { Bayram, Özel Gün Kutlama, Başsağlığı, } \\
\text { Anma }\end{array}$ & 42 & 6,3 \\
\hline Diğer Kurumlarla Etkileşim & 124 & 18,5 \\
\hline TOPLAM & $\mathbf{6 7 0}$ & $\mathbf{1 0 0 , 0}$ \\
\hline
\end{tabular}

Kaynak: Yazar tarafindan hazırlanmıştır. 
Grafik 16. Kültür ve Turizm Bakanlığının Paylaştığı Tweetlerin Kodlar Arası Dağılımı

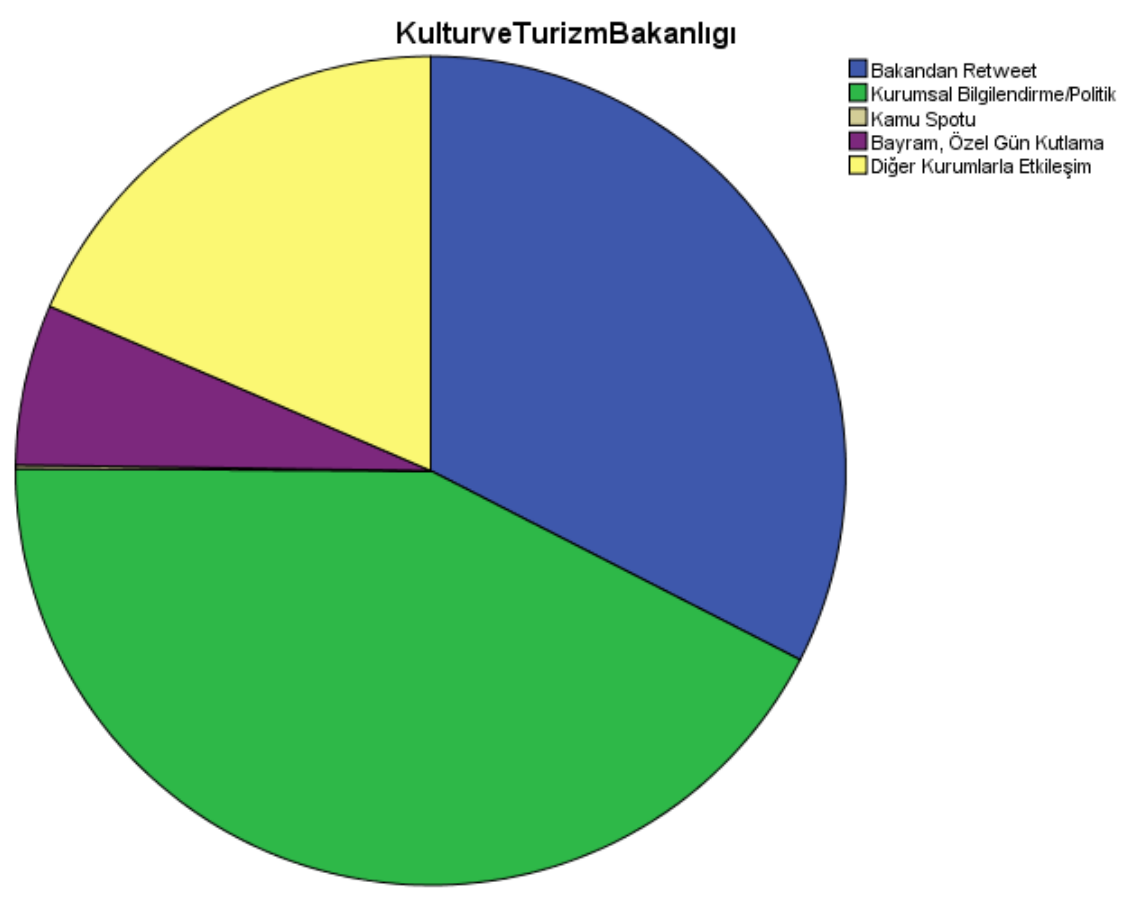

Kaynak: Yazar tarafindan hazırlanmıştır.

Paylaştı̆̆ı tweetlerin sayısı baz alındığında, Kültür ve Turizm Bakanlığı da Twitter'ı aktif kullanan bakanlıklar arasında yerini almıştır. Bakanlık tarafından paylaşılan tweetlerin büyük oranı "Bakandan Retweet" ve "Kurumsal Bilgilendirme/Politika Bildirimi” kodları arasında dağılım göstermiştir. Bunun yanında, "Diğer Kurumlarla Etkileşim" kodu içerisinde kendine yer bulan tweetlerin sayısı da azımsanmayacak bir orandadır. Kurum kutlama, tebrik, başsağlığı ve anma temalı tweetleri genel olarak kendi kurumsal Twitter hesabından paylaşmışır.

\section{SONUÇ VE DEĞERLENDİRME}

Özellikle 2000'li yılların başından itibaren gelişen, kullanımı yaygınlaşan bilgi ve iletişim teknolojileri, insan hayatında önemli bir yer edinmiştir. İnternetin Web 1.0'dan Web 2.0'a dönüşümü, bunun bir yansıması olarak ortaya çıkan sosyal medya, geleneksel medyanın yerini almış ve günlük hayatta kullanılan bir iletişim aracı haline gelmiştir. Öncelikle vatandaşlar arasında kullanımı hızla artmış ve bunun sonucunda asli görevi vatandaşa hizmet olan devlet kurumları da vatandaşlarına daha etkin, etkili ve verimli hizmet vermek amacıyla sosyal medyayı kullanmaya başlamışlardır. Türkiye Cumhuriyeti Bakanlıklarının sosyal medyanın önde gelen platformlarından Twitter üzerinden inceleyen bu çalışmada, söz konusu bakanlıkların tümünün platform üzerinde resmi hesaplarının bulunduğu belirlenmiștir. Buradan hareketle Türkiye'de merkezi yönetimin de Web 2.0 'ın bir yansıması olan sosyal medya kullanımına ayak uydurduğu söylenebilecektir. Bakanlıkların paylaştıkları tweet sayıları dikkate alındığında, genel olarak Türkiye'deki bakanlıkların Twitter platformunu aktif olarak kullandıkları söylenebilecektir.

Bakanlıkların resmi Twitter hesapları üzerinden 2019 yılında paylaştıkları, toplamda 8883 adet tweet analiz edildiğinde bir takım çarpıcı sonuçlar ortaya çıkmıştır. Bunlardan ilki hiç şüphesiz ki, araştırmacının ek bir kod olarak türettiği ve bakanlıklarda Twitter kullanımında vatandaş katılımı boyutunu ölçen "Vatandaştan Fikir Alma/Anket" kodu analizinin sonucudur. Araştırmada, bakanlıklar tarafindan paylaşılan 8883 tweet içerisinden sadece 7 tweet bu kod içerisinde yer almıştır ve bu konuda en aktif bakanlık Sağlık Bakanlığı olmuştur. Twitter'ın son yıllarda geliştirdiği ve kullanıma sunduğu bir anket uygulaması vardır. Twitter hesabına sahip kişi ya da kurumlar bu uygulama sayesinde takipçilerine anket formatında çeşitli sorular sorarak çoktan seçmeli cevaplar alabilmektedir. Böyle bir imkân varken, bakanlıkların bazı politikalarda ya da uygulamalarda vatandaştan fikir alması, beklenen fakat ulaşılamayan bir sonuç olmuştur. Bunun ötesinde bakanlıklar, gerçekleştirdikleri icraatlar ve verdikleri hizmetlerin dönütlerini de bu uygulama sayesinde alabilecek 
durumdayken, genel olarak böyle bir yöntemi tercih etmemişlerdir. "Vatandaştan Fikir Alma/Anket" kodu içerisinde yer alan tweet sayısının bu denli az oluşu, bakanlıkların Twitter'ı bir "sivil katılım" ve "dönüt alma" aracı olarak kullanmadıklarını göstermektedir. Oysa ki Web 2.0 ve sosyal medyanın en büyük özelliği ve getirisi "etkileşim" ve "anlık geribildirim"dir.

Araştırmanın analiz sonuçlarına göre Türkiye'deki bakanlıkların Twitter'ı birincil kullanım amacı "kurumsal bilgilendirme ve politika bildirimi”" olarak belirlenmiştir. Bakanlıkların paylaştıkları tweetlerin çok büyük bir oranı bu amaçla paylaşılmıştır. Yapılan icraatlar, bakanların günlük, haftalık ya da aylık programları, yapılacak icraatlar ve benimsenen politikalar kurumların resmi Twitter hesapları üzerinden sıklıkla paylaşılmışıtır. Burada tek taraflı bir iletişim söz konusudur. Geleneksel medya araçlarından olan radyo, televizyon ve gazete gibi platformlardan ya da Web 1.0 içerisinde yer alan interaktif olmayan internet sitelerinden de yapılabilecek olan bu işlemler sosyal medya üzerinden gerçekleştirilmiştir. Yani, Web 2.0'ın getirilerinden ve özelliklerinden yararlanılmamış, Web 1.0 kullanımı ve anlayışı Web 2.0 üzerinden devam ettirilmiştir. Zira televizyonlarda yayınlanan bakanlık tarafından oluşturulan kamu spotlarına tam sayıda olmasa da bu platform üzerinde de yer verilmiş ve bunlar paylaşılmıştır. Genel olarak sosyal medyanın kullanım pratikliği ve basitliği ancak bu anlamda kurumlara bir avantaj sağlamış, etkileşim ve iletişim fonksiyonundan vatandaş yararlandırılmamıştır.

Kurumsal bilgilendirme ve politika bildirimi dışında, bakanlıkların tweetlerinin önemli bir bölümü, bakanların paylaştıkları tweetlerden yapılan retweetler olarak belirlenmiştir. Bakanların geçici fakat kurumların kalıcı (ya da "daha kalıcı" demek daha doğru olabilir) olduğu düşünüldüğünde, özellikle kurumsal bilgilendirme, politika bildirimi ile özel gün kutlama, tebrik, başsağlığı, anma tweetlerinin kurumun resmi Twitter hesabından ayrıca paylaşılmasının daha doğru olduğu düşünülmektedir. Böylece olması gerektiği düşünülen şekilde, bakanların Twitter hesapları daha kişisel, bakanlıkların Twitter hesapları daha kurumsal olabilecektir. Zira yapılan araştırmada Türkiye'de, bakanlık resmi Twitter hesapları ile bakanların kişisel Twitter hesaplarının birbiri arasında fazla etkileşimli ve ikame şekilde kullanıldığı, hesapların birbiri arasındaki sınırların çok bulanık olduğu gözlemlenmiştir. Bunu en belirgin şekilde Çevre ve Şehircilik Bakanlığı ile Aile, Çalışma ve Sosyal Hizmetler Bakanlığının özel gün kutlama, tebrik, başsağlığı ve anma temalı tweet paylaşımlarından görmek mümkün olmuştur. Çevre ve Şehircilik Bakanlığında bu tweetler bakandan yapılan retweetler ile ikame şekilde paylaşılırken, Aile, Çalışma ve Sosyal Hizmetler Bakanlığında ise diğer kurumlardan retweetlenen (etkileşimde bulunulan) tweetler ile paylaşılmıştır. Kurumlar bu tür tweetleri genellikle birincil şekilde paylaşmamayı tercih etmişlerdir. $\mathrm{Bu}$ temadaki tweetlerin bakanlıkların resmi (kurumsal) Twitter hesaplarından birincil (kurum tarafından yazılmış) tweet olarak paylaşmalarının, takipçileri nezdindeki kurumsal kimliklerini daha da pekiştireceği düşünülmektedir. Bu açıdan, bakanlar aynı içerikteki ve temadaki tweetleri kendi kişisel Twitter hesaplarından paylaşsalar da, kurumlar da bu tweetleri kendi kurumsal hesapları üzerinden birincil olarak paylaşmalılardır.

Bakanlıkların paylaştıkları tweetlerde, kendi alt birimleri ya da diğer bakanlıklar, dernekler, kampanya ve oluşumlarla yoğun olarak etkileşimde bulundukları gözlemlenmiştir. Bu durum kurumlar arası diyalog, işbirliği ve koordinasyonun artması açısından önemli ve olumlu bulunmuştur. Adalet Bakanlığı örneğinde daha belirgin olarak gözlemlenen, bakanlığa ait alt birimlerin kendi Twitter hesaplarını oluşturarak daha çok kurumsal bilgilendirme niteliğindeki tweetleri bu hesaplardan paylaşması bir nebze parçalı bir görüntü oluşturmaktadır. Zira yeteri bilgi ve birikime sahip olmayan takipçi vatandaş bunları iki ayrı kurum olarak algılayabilecek, bu durum da kurumun vatandaşın algısında karışıklığa yol açabilecektir. Diğer yandan paylaşılan tweetlerin özellikle bir alt birim tarafından paylaşılıyor olmasının o birimle ilgili ve ilişkili olanlar dışında vatandaş açısından çok önemli olmayacağı düşünülmektedir. Bu düşünceyi, bakanlıkların genelinde böyle bir uygulama olmaması durumu da bir nebze desteklemektedir. Bu sebeple alt birim hesaplarının bakanlık hesab1 ile birleşmesinin ve söz konusu tweetlerin yalnızca bakanlık hesabından paylaşılmasının daha uygun olacağı düşünülmektedir.

Kalın çizgilerle altını çizmek gerekir ki bakanlıkların Twitter kullanımdaki en büyük eksik, hesapları takip eden vatandaşların katılım boyutunun güçlendirilmesidir. Twitter'da bu konuda çok büyük kolaylık sağlayacak anket uygulaması, bakanlıklar tarafından bir takım politikalar üretilirken vatandaşlardan fikir alma ve gerçekleştirilen icraatlar konusunda dönüt alma gibi fonksiyonlarda kullanılabilecektir. Bunun ötesinde, ilerleyen zamanlarda bakanlıklar bünyesinde, çağrı merkezlerinde olduğu üzere çalışanlar görevlendirilerek takipçi vatandaşlardan tweet ya da direkt mesaj (DM) yoluyla gelecek soru, görüş ve önerilere cevap verilebilecektir. 


\section{KAYNAKÇA}

BERGQUIST, Magnus, LJUNGBERG, Jan, REMNELAND, Björn ve ROLANDSSON, Bertil (2017), "From e-Government to e-Governance: Social Media And Public Authorities Legitimacy Work", Proceedings of The 25th European Conference on Information Systems (ECIS), ss.858-872.

BERTOT, John Carlo, JAEGER, Paul T. ve HANSEN, Derek L. (2012), "The Impact of Polices on Government Social Media Usage: Issues, Challenges, And Recommendations", Government Information Quarterly, S.29, ss.30-40.

BRAINARD, Lori A. ve MCNUTT, John G. (2010), "Virtual Government - Citizen Relations: Informational, Transactional or Collaborative?”, Administration \& Society, S.42(7), ss.836-858.

CHO, Seong Eun ve PARK, Han Woo (2012), “Government Organizations' Innovative Use of The Internet: The Case of The Twitter Activity of South Korea's Ministry For Food, Agriculture”, Forestry And Fisheries, Scientometrics, S.90, ss.9-23.

CHUN, Soon Ae, SHULMAN, Stuart, SANDOVAL, Rodrigo ve HOVY, Eduard (2010), "Government 2.0: Making Connections Between Citizens, Data And Government”, Information Polity, S.15, ss.1-9.

ÇiLDAN, Cihan, ERTEMİ, Mustafa, KÜÇÜK, Evren, TUMUÇİN, H. Kaan ve ALBAYRAK, Duygu (2012), "Sosyal Medyanın Politik Katılım ve Hareketlerdeki Rolü", Akademik Bilişim 2012 Konferansı Bildiriler Kitabı, 1 Şubat 2012 - Uşak, ss.1-9.

GÖÇOĞLU, Volkan (2014). "Kamu Politikası ve Sosyal Medya İlişkisi”, Yüksel Lisans Tezi, Hacettepe Üniversitesi Sosyal Bilimler Enstitüsü, Ankara.

KHAN, Gohar Feroz, YOON, Ho Young ve PARK, Han Woo (2014a), "Social Media Communication Strategies of Government Agencies: Twitter Use in Korea And The USA", Asian Journal of Communication, S.24(1), ss.60-78.

KHAN, Gohar Feroz, YOON, Ho Young ve PARK, Han Woo (2014b), "From e-Government to Social Government: Twitter Use By Korea's Central Government”, Online Information Review, S.38(1), ss.95-113.

MCDERMOTT, Patrice (2010), "Building Open Government”, Government Information Quarterly, S.27, ss.401-413.

MCNUTT, Kathleen (2012), "Social Media \& Government 2.0", Johnson-Shoyama Graduate School of Public Policy, University of Regina.

O'REILly, Tim (2007), “What Is Web 2.0: Design Patterns And Business Models for The Next Generation of Software”, Communications \& Strategies, S.65(1), ss.17-37.

OSBORNE, David ve GAEBLER, Ted (1992), Reinventing Government: How the Entrepreneurial Spirit is Transforming The Public Sector, Plume, New York.

ROOKSBY, John ve SOMMERVILLE, Ian (2012), "The Management and Use of Social Network Sites in a Government Department", Computer Supported Cooperative Work, S.21, ss.397-415.

TAVŞANCIL, Ezel ve ASLAN, Esra (2001), İçerik Analizi ve Uygulama Örnekleri, Epsilon Yayınları, İstanbul.

WHITE HOUSE (2009), "Memorandum on Transparency And Open Government", Available, http://edocket.access.gpo.gov/2009/pdf/E9-1777.pdf (Erişim Tarihi: 20.07.2019). 